Highlights for

The Volcano-Sedimentary Succession of the Archean Sodium Group, Ventersdorp

Supergroup, South Africa: Volcanology, Facies and Geochemistry

Wladyslaw Altermann*, Nils Lenhardt

Department of Geology, University of Pretoria, 0002 Pretoria, South Africa

1. Archean volcano-sedimentary succession of the Sodium Group

2. Largest LIP of the Kaapvaal Craton

3. Geochemical and sedimentary facies

4. Correlation to Ventersdorp Supergroup 
The Volcano-Sedimentary Succession of the Archean Sodium Group, Ventersdorp

Supergroup, South Africa: Volcanology, Facies and Geochemistry

Wladyslaw Altermann ${ }^{*}$, Nils Lenhardt

Department of Geology, University of Pretoria, 0002 Pretoria, South Africa

* Corresponding author: Department of Geology,

University of Pretoria,

Pretoria 0002

South Africa

Tel.: $\quad$ ++27(0)12 4203310

Fax: $\quad$ ++27(0)123625219

E-Mail: wlady.altermann@up.ac.za

Manuscript to be submitted to

Precambrian Research (special volume for Wulf Mueller) 


\title{
The Volcano-Sedimentary Succession of the Archean Sodium Group, Ventersdorp Supergroup, South Africa: Volcanology, Facies and Geochemistry
}

\author{
Wladyslaw Altermann, Nils Lenhardt \\ Department of Geology, University of Pretoria, 0002 Pretoria, South Africa
}

\begin{abstract}
The volcano-sedimentary succession of the Sodium Group, in the south-western corner of the Kaapvaal craton, rests unconformably on basement granites and is usually correlated with the lower and middle Ventersdorp Supergroup. This Neoarchean ( 2700 Ma) large igneous province (LIP) has been interpreted as deposited in a tectonic escape basin scenario, following the collision of the Zimbabwe and Kaapvaal cratons, or alternatively, in a mantle plume induced, cratonic rift basin. The basaltic-komatiitic to andesitic-dacitic volcanic sequence and the accommodated sedimentary deposits developed in a graben to half-graben setting in a cratonic, failed-rift system.

The Sodium Group sedimentary facies and geochemistry of volcanic rocks correlate well with the Ventersdorp Supergroup. The Ongers River, T'Kuip and Omdraaivlei Formations reflect sedimentation and volcanism in a rift induced graben setting with fast sedimentation from horst flanks and high burial rates in the graben valleys, and subsequently, a less pronounced topography, post-graben environment. Accompanying magmato-phreatic and extrusive, mafic to acidic, bimodal volcanism, with abundant pyroclastics, delivered ample material for graben fill deposits. Repeated horst reactivation has episodically exposed the basement to renewed erosion. Sedimentation along graben flanks comprised alluvial fans, mass flow deposits, braided river and related modes of deposition. In distal, shallow lakes, volcaniclastic suspension and current sedimentation, low-density turbidites and stromatolitic reefs were accumulated.
\end{abstract}

\section{Keywords:}

Ventersdorp Supergroup; Archean Volcano-sedimentary Successions; Kaapvaal Craton; Sodium Group; Omdraaivlei, T'Kuip, Ongers River Formations. 


\section{Introduction:}

The present paper was written in memory of Wulf Müller, a friend for more than 20 years, since we took part together in a geological excursion across the Pilbara craton, a formidable sedimentologist, Precambrian geologist and volcanologist, Editor in Chief of the "Precambrian Research" and a good cook, hockey player and fisherman. We did many projects together an had a lot of fun doing science and visiting geological sites around the globe Wulf's unique sense of humour was always a good company. In 2009, Wulf has visited the Department of Earth and Environmental Sciences in Munich, Germany as guest of W.A. We have worked on the origin of microtubules in Archean pillow rims and on petrology of Phanerozoic reservoir sandstones from North Germany. Unfortunately this work will now, for long, remain unfinished. Wulf had a lot of interests, the Ventersdorp Supergroup was one of the question marks for him. The lack of monomict conglomerates, as described from North America (Corcoran and Mueller, 2002) in the Ventersdorp Supergroup, was one of the discussed questions, next to the general tectonic setting of this volcano-sedimentary succession. Wulf has assumed that the abundance of granitic and feldspar rich boulders and cobbles in the manifold Ventersdorp conglomerates reflects a very fast sedimentation, in an unstable, tectonically active extensional horst and graben setting. Fast burial prevented the clasts from being decomposed in the $\mathrm{CO}_{2}$ rich Archean atmosphere. With this contribution we hope to answer few of the questions Wulf has put forward in many discussions during his 12 months stay in Munich and all the years before.

The Sodium Group of the Archean Ventersdorp Supergroup (Grobler et al., 1989), is the main subject of the present contribution. It is famous for its well preserved raindrop imprints, which are among the oldest known such structures on Earth (van der Westhuizen et al., 1989). The aim of the present study is to present new sedimentary and volcanic facies and geochemical data of the Sodium Group. The Sodium Group, outcropping in Griqualand West, south-east of Prieska, between Prieska and Britstown, on the farm Omdraaisvlei, is usually correlated with the midle part of the Ventersdorp Supergroup (SACS, 1980; 1995; Geological Map of South Africa 1: 250000, 3022 Britstown. 1991; van der Westhuizen, 2006). It is little known and poorly described, apart form the famous raindrop outcrops. Next to the Zoetlief Group around Vryburg, or the Zeekoebaart Formation, outcropping west of Prieska and Westerberg, the Sodium Group represents one of the (south) western most outliers of the Ventersdorp volcanism on the Kaapvaal craton (Fig. 1). These outliers have been given differing names 
because of the lack of continuous outcrops between them and the main outcrop area of the Ventersdorp Supergroup. However, they all rest unconformably on the Archean crystalline and metamorphic basement and are all unconformably covered by the sedimentary successions of the Transvaal Supergroup (2642- $2050 \mathrm{Ma}$ ) (for an overview see Eriksson et al., 2001; van der Westhuizen et al., 2006).

\section{The Ventersdorp Supergroup:}

The Ventersdorp Supergroup is a volcano-sedimentary sequence, of c. 4 on average, and up to $8 \mathrm{~km}$ thickness, predominantly composed of sub-aerial lavas and pyroclastics and of mainly lacustrine siliciclastic and less abundant carbonate sedimentary rocks (van der Westhuizen et al., 1991; 2006). It covers an elongated area of c. $300000 \mathrm{~km}^{2}$ and more than $750 \mathrm{~km}$ along NE strike, between Johannesburg and Marydale (Pretorius, 1976; van der Westhuizen, 2006) and is best exposed in the southern and western Transvaal basin, in the Northern Cape Province and south-eastern Botswana (van der Westhuizen et al., 1991). With this extend and thickness, the Ventersdorp Supergroup represents the largest "Large Igneous Province" or "LIP", of the Kaapvaal Craton (Fig. 1). Within this regional extend, the role of the Kanye Volcanic Formation, present in Botswana is not clear, as the stratigraphic relationship of the Kanye Volcanics to the Ventersdorp Supergroup is not well constrained. The Kanye Volcanic Formation in Botswana, might be correlated with the lower Ventersdorp Supergroup, as both are overlain by the Transvaal Supergroup. However the Kanye Volcanic Fm. was dated at

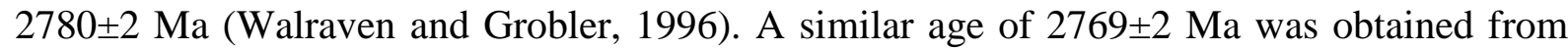
the Derdepoort outlier, E of Gaborone, on the border to South Africa (Walraven and Grobler, 1996), and regionally between the Kanye and the Ventersdorp proper outcrops.

Based on the occurrence of volcanic rocks of varying geochemistry and on intercalated tuffs and sedimentary rocks (Winter, 1976; SACS, 1980), the Ventersdorp Supergroup is subdivided in stratigraphic order into the Klipriviersberg Group (2714 \pm 8 Ma, SHRIMP on zircons; Armstrong et al., 1991), the Platberg Group (2709 \pm 4 Ma, SHRIMP on zircons; Armstrong et al., 1991) and the Pniel Group, which is so far not dated. Olsson et al. (in press) however, suggest that the Allanridge volcanics of the Pniel Group may be age equivalent with a 2.66-2.68 Ga dyke swarm in the north eastern Kaapvaal craton. It is therefore probable, that the Ventersdorp Supergroup volcanism and sedimentation cover a time span of c. 70 myr and more, but maximally 140 myr (2642 Ma for the Vryburg lava in the lower most Transvaal Supergroup; Walraven and Martini, 1995; Altermann, 1996). 
The geochemistry of the Ventersdorp extrusive volcanic rocks ranges from komatiites and basalts, to andesites, trachytes and dacites. Komatiites are present in abundance, in the lower part of the succession and reappear towards the top of the supergroup. The 3 major groups of the Ventersdorp Supergroup represent three unconformity bound units (Table 1): The basal, c. 1.5-2 km thick, flood basalts and komatiites are summarized as the Klipriviersberg Group. They are unconformably followed by the medial graben-fills of the mixed, siliciclasticvolcaniclastic and extrusive volcanic Platberg Group, of up to $1800 \mathrm{~m}$ thickness. The unconformably succeeding Pniel Group consist of c. 400 m thick Bothaville Formation clastic sedimentary rocks, followed by the c. $750 \mathrm{~m}$ thick Allanridge flood basalts, which again, are partly komatiititic (van der Westhuizen et al., 1991; 2006). In some publications, the Pniel Group is regarded as informal and does not appear in the stratigraphic column (van der Westhuizen et al., 2006, following Winter, 1976), who noted the profound lithological difference between the Bothaville and Allanridge Formations. The thickness of the particular groups and formations varies strongly, depending on the local development and preservation and disconformities developed within the different formations.

\section{Insert Figure 1 here}

The unconformities between the three main groups are major and of regional extent and the position of the depocenters changes with each unconformity. Equally, the marginal facies of the basins and thus the lateral extent of the groups vary considerably and each group can start on older volcano-sedimentary rocks or on basement granites and gneisses, depending on the distance to the depocentres of the respective group (comp. below). The unconformity between the Platberg and the Pniel Groups was proposed in the past to represent the Archean Proterozoic boundary on the Kaapvaal craton (Cheney et al., 1990). Dating of the overlying Transvaal Supergroup however has shown that the unconformity below the Transvaal still falls within the Neoarchean Eon (Walraven and Martini, 1995; Altermann and Nelson, 1998).

The angular unconformity below the Ventersdorp Supergroup represents a major time gap across the Kaapvaal craton. In its marginal parts the supergroup follows a minimum of 100 myr time gap in geological record (Maphalala and Kröner, 1993; Beukes and Nelson, 1995) marking an erosive removal of up to $\sim 1.5 \mathrm{~km}$ of stratigraphy (Hall, 1996). It overlies the volcanic rocks of the Dominion Group $(\sim 3.0 \mathrm{Ga})$ and the sedimentary Witwatersrand 
Supergroup ( $2.9 \mathrm{Ga})$, in the central part of the Transvaal basin. In the west, the Ventersdorp Supergroup covers greenstone belts and TTGs of > 3000 to $2900 \mathrm{Ma}$, with $2729 \pm 3 \mathrm{Ma}$ volcanic rocks (Poujol et al., 2005).

Towards the edges of the basin, the Ventersdorp Supergroup overlies with its varying groups and formations, crystalline and metamorphic basement rocks, marking thus a significant and regionally extensive angular unconformity. An angular unconformity is also reported between the lower Witwatersrand and the overlying Ventersdorp Supergroup, in the west of the basin (Tankard et al., 1982; Winter, 1987). However, the Ventersdorp Supergroup may rest conformably on the Witwatersrand in the Central Rand (Linton et al., 1990), East Rand, the Heidelberg area (Nel and Jansen, 1958), and the Orange Free State Goldfield (Coetzee, 1960).

Together with the Dominion Group and the Witwatersrand Supergroup the Ventersdorp constitutes the Randian Era (3.1-2.65 Ga). Traditionally, these three unconformity bound units have been grouped into what has become known as the "Witwatersrand triad" (Hamilton and Cooke, 1960), a collective term acknowledging their close spatial, structural and temporal association in "a major geological cycle" (Brock and Pretorius, 1964; Clendenin et al., 1988a; b).

Insert Table 1 here.

\section{Geological setting:}

The geodynamic, depositional scenario of the Ventersdorp Supergroup is controversial. Geodynamic models rely on interpretations of the geochemistry of extrusive rocks and on interpretations of sedimentary deposits.

The collision of the Zimbabwe and Kaapvaal craton along the Limpopo Belt in the north, is supposed to have caused the development of large fractures in the crust, formation of grabenlike basins and the release of extensive lava flows through fissures during the Ventersdorp times. In this scenario the Ventersdorp basin was viewed as one of "successor basins" including the Dominion, Witwatersrand and Transvaal basins (Clendenin et al., 1988a; b). The location of depocenters, morphology and magmatism within these basins was thought to reflect different angles and velocities of subduction beneath the Kaapvaal Craton. The problem lies however in the poor understanding of this subduction and the collision between 
Kaapvaal and Zimbabwe Cratons, and in the controversial interpretations of its duration somewhere between 3.3 and 2.0 Ga (summarized in Kramers et al., 2006).

The sedimentation of the Venterspost Formation and the continental, terrestrial extrusion of volcanic rocks (Klipriviersberg Group) on the Kaapvaal Craton mark the onset of deposition of the Ventersdorp Supergroup. The Venterspost Formation, also known in its basal part as the Ventersdorp Contact Reef consists of thick, polymict, and structurally immature conglomerates and grits of varying clast sizes, intercalated with tuffaceous sandstones, lavas and shales. These very dynamic, high energy sedimentary deposits were interpreted as having been deposited in topographic undulations caused by a compressional regime (Henning et al., 1994). The character of the deposits and the geochemistry of the lavas (basalts and komatiites), however, rather suggest a deep faulted, extensional, cratonic graben setting. Numerous unconformities separate the lower sedimentary cycles of the Venterspost Formation (e.g. Germs and Schweitzer, 1994) and mark lateral shifting of depositional facies by tectonic movements along graben boundary faults and rapid filling of the depositories by volcano-sedimentary detritus, accompanied by extensive extrusive volcanic activity. It has been proposed that as pressure from the north continued, parts of the craton began to slide sideways to accommodate the stress, causing the development of a system of half-grabens and linear fault troughs (Buck, 1980; Clendenin et al., 1988a; b; Grobler et al., 1989). Fan-shaped aprons developed at these troughs, shedding debris-flow deposits and fluvial sediments into the basins, where lacustrine deposition with fine-grained terrigenous and chemical sediments, including stromatolites and ooids prevailed. Clendenin $(1988 \mathrm{a} ; \mathrm{b})$ interpreted the upper Klipriviersberg Group as a post-graben tectonic subsidence stage. Later sedimentation was periodically interrupted by bimodal mafic to felsic volcanism, resulting in the accumulation of thick lava flows and pyroclastics (Platberg Group). According to Buck (1980), graben development was virtually complete by the end of the deposition of the Platberg Group. The Platberg Group is subdivided from base to top in stratigraphic order into four formations: the Kameeldorings, the Goedgenoeg, the Makwassie and the Rietgat Formation (Table 1). The Pniel Group above the Platberg is again a succession of sedimentary and volcanic, subordinately komatiitic to mainly andesitic extrusive rocks whereby the lower formation (Bothaville) is mainly tuffaceous-sedimentary and the upper Allanridge is of basalticandesitic and komatiitic lava flows. 
The currently prevailing point of view is that at the end of the Witwatersrand sedimentation, the Kaapvaal Craton underwent intense uplift and rupturing (Eriksson et al., 2001). In a review by Eriksson et al. (2002) a mantle plume model has been applied to the Ventersdorp Supergroup, following Hatton, 1995. According to this model, crustal extension, probably caused by thermal elevation related to a mantle plume beneath the Kaapvaal craton, led to the development of a set of graben and half-graben depositional basins, forming the basis for the Klipriviersberg volcanics, and the wedge-shaped clastic and bimodal volcanic rocks of the Platberg Group (van der Westhuizen et al., 1991, and references therein). The uppermost continental sedimentary sheet cover of the Bothaville and Allanridge Formations suggest thermal subsidence marking the plume perishing, which however disagrees with the occurrence of komatiites in this succession. Nevertheless, the model makes up for the poor constraints on the age of the Kaapvaal-Zimbabwe collision and for the wide extend of the Ventersdorp Supergroup, that is difficult to explain by the Limpopo mobile belt, generally striking approximately E-W.

The large volume of mafic extrusive rocks within the Ventersdorp Supergroup, typical of LIP, has ruled the geodynamic discussions of the Ventersdorp Supergroup. Crow and Condie (1988) were first to show a large quantity of geochemical data for various Ventersdorp formations and to demonstrate their mantle source, with varying crustal contamination. The different formations however, have alternating, bimodal geochemistry, which has been explained by either different mantle sources (Crow and Condi, 1988) or by fractional crystallisation and differentiation in magma chambers (Marsh et al., 1992) The large differences between e.g. Klipriviers lavas and Allanridge lavas however, imply different magmatic events with different magma sources for some of the formations (Nelson et al., 1992), while the Makwassi porphyries might rather represent magma mixing and stronger crustal contamination (Bowen et al., 1986). A mantle plume related model has been repeatedly proposed for the Ventersdorp basin development (e.g. Hatton, 1995; Eriksson et al., 2002).

The entire Ventersdorp Supergroup is greenschist-facies metamorphosed, which is attributed to autohydrothermal and burial, regional processes as has been described by many authors (summarized in van der Westhuizen et al., 2006). 
The ages for the Klipriviersberg and Platberg Groups are within the statistical uncertainty of the date of $2714 \pm 3 \mathrm{Ma}$ determined for the Kareefontein Formation of quartz porphyry, rhyolite and trachyte, from the south-western Kaapvaal craton by Walraven et al. (1991). The Kareefontein Formation is a part of the Zoetlief Group, resting on Archean granites and composed of conglomerates and arkoses of the Oasis Formation, known only from boreholes in the vicinity of Vryburg, the Kareefontein Formation and the overlying Vogelvlei Formation of tuffs, breccias, thin limestones and cherts interbeded with trachytes and andesites. The Vogelvlei Fm. is followed by the Bothaville and Allanridge Formations of the Pniel Group (Visser, 1989).

\section{The Sodium Goup:}

The present study presents new facies and compositional data from the Sodium Group, resting unconformably on granitoid basement rocks dated between $2938 \pm 5$ to $2718 \pm 8 \mathrm{Ma}$ (McCourt et al., 2000). The Sodium Group is generally correlated with the Platberg Group (SACS; 1980; van der Westhuizen, 2006), and consists of the Ongers River Formation of basal conglomerates, grits and tuffs, overlying the Skalkseput, Dragoender, or unnamed granites. The basement rocks are even less investigated than the Sodium group and their regional correlation are purely following circumstantial evidence like the degree of deformation, occurrence of certain mineralogy and texture etc. The T'Kuip Formation of quartz and feldspar porphyries, tuffs and arkoses and the uppermost Omdraaivlei Formation of mafic lavas interbedded with arkoses and thin stromatolitic and silicified limestones (cherts) follow the Ongers River but have a larger cover area each overlapping directly on the basement rocks as well (SACS, 1980). According to Grobler et al. (1989), the Omdraaivlai Formation can be correlated with the Rietgat Formation, outcropping in the area around Britstown (Fig. 1). However, both formations are still lacking precise geochronological and compositional data. Our work contributes to the petrogenesis of the volcanic rocks, and provides constraints on the magmatism and to possible correlation of the isolated outcrops of the Sodium Group, to other parts of the Ventersdorp Supergroup.

Earlier work on the Sodium Group comprises of descriptions by Rogers (1906), Du Toit (1908), Emslie (1972). Various names were given to the volcano sedimentary formations between Britstown and Prieska (Fig. 1) by the different workers. The correlation to the Ventersdorp Supergroup is based on the work of Grobler and Emslie (1976) and Winter (1965) as summarised by (SACS 1980). Van Niekerk and Burger (1978) obtained an age of 
$2620 \pm 50 \mathrm{Ma}$ from zircons in the Makwassi quartz porphyry that is usually correlated on petrographical and geochemical grounds with the T'Kuip quartz porphyry.

There is some confusion in the literature as to the spelling of Omdraaivlei Formation and T'Kuilp Formation. With new editions of the various topographic and geological maps, the spelling has changed. Herein, we stick to Omdraaivlei Formation and T'Kuip Formation as used in SACS, 1980 and in the Explanations to the Geological Map of South Africa 1: 1000000. The farm names are spelled mostly as Omdraaisvlei or Omdraai Vlei, 'T Kuip, T' Cuip, or Kuip.

\section{Materials and methods}

Field work was carried out on the Omdraaisvlei and Kuip farms, SE of Prieska, between Prieska and Britstown. Here, a stratigraphic section, ca. $540 \mathrm{~m}$ in thickness, was logged and sampled for volcanological, sedimentological and geochemical analysis (Fig. 5). Furthermore, a lithofacies analysis was carried out following the terminology of McPhie et al. (1993).

Between the farms Kuip and Omdraaisvlei on the Geological Map of South Africa 1: 250 000, 3022 Britstown, the outcrops of the succession of Ongers River, T'Kuip and Omdraaivlei Formations cover basement rocks and are followed unconformably by the Phanerozoic Karoo Supergroup which is in contact to all older rocks. The general dip of the beds and lava flows is c. 10-30 degrees to the NW or NNW. In the following we concentrate on our own observations if not otherwise stated.

\section{Insert Figure 2 here}

\section{Ongers River Formation}

The Ongers River Formation rests directly on the irregular but flat, and topographically deeply denudated basement, consisting of various granitoid rocks, gneissic granites and basaltic dikes. The ages of the basement are poorly constrained in the outcrop area (see above), but their varying degree of structural and metamorphic overprint is clearly visible in the field. All the basement rocks are abundantly represented as cobbles (up to over $50 \mathrm{~cm}$ in diameter) and pebbles in the thick, very coarse, poorly sorted, and clast-supported conglomerates, resting directly on the basement. Further upwards the conglomerates become somewhat finer and more gritstones, graywackes, arkoses and immature sandstones are 
intercalated, however, conglomerate lenses and beds occur throughout the formation and are everywhere structurally and compositionally immature. Nevertheless the coarsest conglomerates occur at the base of the section and the amount of finer sedimentary rocks increases towards the top of the formation.

\section{Insert Figure 3 here}

The coarse sandstones to fine conglomerates display often pinching out beds of planar cross bedded strata with cross bed sets of few $\mathrm{cm}$ to $30 \mathrm{~cm}$ amplitude. Current induced graded bedding, fining upward, without significantly better sorting upward, is common. In a typical turbiditic graded bedding, the clast size sorting must improve upwards as the larger clasts settle down faster and disappear in the graded bed upwards. Such graded bedding has also been found in many beds (compare lithofacies description below). Thin, planar beds or laminae of coarser clasts, interbedded in sandy material, that are typical of flash floods are however, common in these beds (Fig. 2).

The outcrops are forming several steep ridges, becoming less steep where softer, psammitic (abundand arkoses) and pelitic rocks (tuffaceous shales) are concentrated. The high topography, less eroded outcrops of the Ongers River coarse clastics, relatively to the low lying basement rocks, is probably due to a reciprocal recent relief relationship to the paleorelief, with the basement rock horsts having eroded faster than the lava flows on top of the thick clastic graben fills. According to our observations the Ongers River Formation is at least $500 \mathrm{~m}$ thick. $460 \mathrm{~m}$ of thickness in the type section were reported by SACS (1980), however, the sedimentary beds have a lenticular nature and the thickness varies strongly with the lateral facies changes.

In the lower part of the Ongers River Formation, starting at few tens of metres above the unconformity, several air-fall ash-tuffs, with intercalated accretionary lapilli and lapilli tuffs are interbedded as thin intervalls in the tuffaceous-psammitic to pelitic sedimentary rocks, exhibiting current cross bedding as evidence of subaqueous re-deposition. Within this facies the 3-5 mm thick ash-fall tuff surfaces display up to $30 \mathrm{~cm}$ wide desiccation polygons (Fig. 3f), curled up, saucer-shaped mud chips and flakes, and resedimented clayley flakes (Fig. 3c, d) often with imprints of atmospheric fallout and perhaps volcaniclastic lapilli impact craters. The imprints have strongly varying density of distribution on the surfaces (Fig. 3a,b,e,g,h). 
Some of these structures were interpreted as imprints of Archean raindrops (van der Westhuizen et al., 1989). We agree with this interpretation, especially in cases such as shown in Fig. 3b, e, h, i, but the large, up to $1 \mathrm{~cm}$ in diameter and $5 \mathrm{~mm}$ deep craters shown in Fig. $3 \mathrm{~g}$, seem too large and too deep to be caused by water drops impacting the unconsolidated volcanic ash mud. We suggest that large hail grains might have caused these craters. Another explanation for these abnormaly large impact ctarers that may contain later smaller craters overprinting the larger structure (Fig. 3g), would be volcaniclastic fall out, but it is difficult to imagine that such fall-out was subsequently washed away without leaving roll and saltation traces behind. This explanation is less probably also because the directly overlying beds do not exhibit such an accumulation of volcaniclastic fallout. The curled up flakes were investigated for the presence of carbon that might indicate microbial mats facilitating the cohesive deformation of these flakes, but no particulate carbon could be detected in the samples neither by petrographic microscope nor by micro-Raman methods. The ash fall layers are abundant in chlorite, sericite and not closer identified other clay minerals, and are strongly silicified.

In the upper part of the Ongers River Formation lava flows appear. Lenses of mafic lava, quartz porphyry and thin lenses of limestone are reported by SACS (1980) but were not encountered in the present work.

The entire Ongers River Formation can be interpreted as basal conglomerate and proximal to distal alluvial fan deposits, shed from the graben shoulders and cut by braided stream deposits, blanketed by flash floods and by lacustrine pelitic-tuffaceous deposits. The general decrease of clast size upward in the formation, and simultaneous increase of the thickness of beds of fine, pelitic to psammitic material, indicates progressively distal deposition from the graben shoulders. Volcanic activity with subaerial ash falls and lava flows was accompanying the deposition of the Ongers River Formation and the topography must have been changing episodically and frequently, creating new base levels and accommodation space and exposing new rocks to erosion. Thus, the tectonic regime must have been of active and frequently occurring movement along the graben confining faults, with constant but sudden subsidence events creating new topographic relief. Atmospheric precipitation must have been abundant occurring as rain and hail, causing flash floods and enhancing the erosion and fast accumulation and burial of sediments. Overall extensional tectonic regime is evident from the above description. 


\section{T'Kuip Formation}

The boundary between the Omdraaivlei and T'Kuip Formations could not be pinpointed in the field. However, the approximately N-S striking low relief hills formed by the lavas and coarse sedimentary deposits are separated by shallow valleys in which fine grained tuffaceous and shale sedimentary rocks prevail. The boundary is hidden in this topography. The upper boundary is defined as the contact between the T'Kuip quartz porphyry to a mafic lava flow of the overlying Omdraaivlei Formation (SACS, 1980). Also this upper contact has not been found in the field, being hidden in the rubble and calcretes covering the low amplitude, smooth valley between the two formations.

The T'Kuip Formation constitutes of massive lava flows, with some porphyritic textures of quartz and plagioclase. Tuffs and arkoses are only subordinate in this formation. SACS (1980) refers to a thickness of $328 \mathrm{~m}$ for the T'Kuip Formation and to almost exclusive occurrence of quartz and feldspar porphyries. Our observations imply that the thickness of the T'Kuip Formation must be significantly lower, perhaps less than half the thickness of the Ongers River Formation. In the field, the measuring of the thickness was not possible because the lava flows are poorly exposed and the flow beds are difficult to differentiate and Jacob's staff can not be used. The porphyroblasts in the porphyritic lava flows can reach up to around $1 \mathrm{~cm}$ across and are scattered throughout the flows but never show a clear fluidal texture. However, in our study the porphyritic lava flows are rather rare and massive and amygdaloidal flows are predominant (Fig. 4). Amygdules are either quartz or calcite filled and concentrate at the bases or tops of the flows. SACS (1980) reports also the occurrence of an ignimbrite layer in this extrusive sequence.

\section{Insert Figure 4 here}

The T'Kuip Formation is interpreted as a tectonically less active period of further subsidence. The grabens must have been filled drowning the horsts in their own detritus. Volcanic flows from the centres aligned along the graben shoulders covered the sediment-filled grabens, further equalising and smoothing out the topography. 


\section{Omdraaivlei Formation}

The Omdraaivlei Formation is a thick sequence of mafic to intermediate lava flows with abundant intercalated sedimentary and volcaniclastic rocks concentrating in the middle of the sequence. This middle part was recorded in detail as it exhibits interesting facies changes (Fig. 5).

The flows are often amygdaloidal, with massive, aphanitic texture in the middle of the flow. SACS (1980), reports angular relationships between the flows in the higher part of the succession, which can be confirmed herein. However, the reported pillow lavas at the top of the succession (SACS, 1980) were not found in the present study.

Approximately 200 metres of lava flows, on average c. $10 \mathrm{~m}$ thick flows, comprise the lower part of the Omdraaivlei Formation. They are followed by an intercalation of a volcanosedimentary sequence deposits of pyroclastic flows, gritstones, arkoses, graywackes, tuffaceous sandstones and conglomerates, further lava flows, and pelitic, tuffaceous deposits and shales interbedded with few several hundred meter long, thin lenses of stromatolitic strongly silicified carbonates. This sequence is 540 m thick, as measured using a Jacob's staff (Fig. 5). Above this section, again few gritstones and fine conglomerate beds occur and lava flows follow for at least $500 \mathrm{~m}$ thickness. In the top 400 metres no sedimentary intercalation was found between the flows.. The total thickness of the formation is recorded to be $1236 \mathrm{~m}$ (SACS, 1980) which agrees well with our observations.

The profile depicted in Figure 5 was recorded here. It starts at a massive lava flow without visible internal structures (bed No. 1). On top of the lava a thin pyroclastic flow with phaneritic, fragmented feldspar crystals and cross bedding sets was deposited. Several tens of metres of various gritstones and conglomerates follow. Internal sedimentary structures are of typical fluvial regime with interbedded lenses of arkoses, clast imbrication in the conglomerates, mostly rounded clasts with alternating clast and matrix support, planar cross bedding at different scales, etc. These coarse sedimentary rocks are covered by sandstones and shales (bed No. 9). Lava flows and gritstones and conglomerates follow for another c. 70m thickness (beds No. 10-14). From there on the sedimentation changes significantly: greenish sandstones (arkoses) and tuffaceous shales prevail, heralding distal, low energy deposition. Nine intervals of carbonate sedimentation were recorded between $190 \mathrm{~m}$ and 400 $\mathrm{m}$ of the profile in Fig. 5. The carbonate beds are thin, just 10 to maximally $90 \mathrm{~cm}$ but strike 
laterally for several hundred metres to about $1 \mathrm{~km}$ distance. All carbonate beds (No. 16; 19, 21 (package of thin silicified carbonates with shale intercalation); 23 (thickest carbonate bed); $25 ; 26 ; 29 ; 30 ; 32$ (bed of small lenses of carbonate) display various stromatolitic and stratiform microbial mat structures and often end upwards with ripple mark horizons, with symmetrical and asymmetrical and climbing ripples which are probably accentuated and preserved because of microbial mat overgrowth and stabilisation of sedimentary grains (Fig. 6). The inclination of some stromatolite columns (LL-H; Logan et al., 1964) is current dependent and leans towards the current as described by Altermann (2007). The carbonate beds are strongly silicified (chertified) and recrystallisation of chert and carbonate is widespread but not pervasive. Strongest silicification has been observed in the thickest stromatolitic bed (No 23). Above the uppermost stromatolitic bed, fine pelitic sedimentation continued for ca $70 \mathrm{~m}$ thickness and with bed 34 the first arkose and sandstone intercalations occur again in the section, followed by gritstones interbedded with tuffaceous shales. The first massive lava flow occurs again with bed No. 39 of the section. From there on only lava flows were encountered.

\section{Insert Figure 5 here}

The Omdraaivlei Formation is interpreted as a continuation of the T'Kuip deposition under similar conditions. The change from quartz porphyry to mafic flows at the bottom does not imply facies wise a depositional difference. Laterally extensive lava flows were deposited on a surface with low topographic relief, beside of the probably higher situated volcanic centres along the pre-existing graben faults. Thin pyroclastic flows, fine to middle coarse conglomerates and coarse to fine arenites evidence relatively distal deposition to the volcanic centres and topographic highs. Further upward in the section, the sedimentation becomes more distal, in a probably lacustrine environment. Pelitic sedimentation and resedimented ash tuffs prevail and during periods of quiescence, the shallow lakes become colonialized by microbial mats resulting in stromatolitic growth. The stromatolites strive however to survive for a long period of time, being repeatedly buried by fine detrital and pyroclastic material. Nevertheless, varying stromatolite morphology ranging form stratiform mats to laterally linked, inclined and vertical columns, develop and grow to the water surface, as evidenced by symmetrical ripple marks, with small water ponds in the ripple troughs structures. Several stromatolitic horizons were counted, the thickest one attaining almost one metre and clearly showing a change in the sedimentary environment during its deposition, reflected by 
vertically changing stromatolite morphology and the occurrence of ripple marks at the top of this bed (Altermann, 2007). Towards the top of this succession, the sediment fans from the more proximal parts of the paleotopographic highs prograde towards the depositional centre of the formation. This progradation of arkoses and grits probably announces the waking up dormant tectonic activity, renewed movements along the faults and subsequent extrusive volcanism, of andesitic to basaltic composition. The angular relationship between the lava flows evidences more pronounced topography, as the surface on which the flows spread and further upward, subaquatic lacustrine deposition of lava is evidenced by the pillow lavas described by SACS (1980).

The onlapping of the successively younger formation on the older one and on the basement rocks (SACS, 1980), towards the margins of the depository, evidences a continuous subsidence of the basin and growing of the basin area. The fast deposition of lavas and sediments however, never allowed for the basin to reach a considerable depth and even the deepest lacustrine deposits probably never exceeded few tens of metres of depositional depth.

\section{Lithology:}

Within the study area seven different volcanic and sedimentary lithofacies types (LFT) were distinguished on the basis of rock type, sedimentary and volcanic structures or textures, and grain size. These main lithofacies types are listed and described below.

\section{LFT 1: Andesitic-dacitic volcanic lithofacies}

This lithofacies is marked by its smooth, sheet-like morphology. In outcrops, it usually shows a flat erosional upper surface and can be traced for several hundred metres. In few localities the upper surface appears to be folded into ropy patterns. Furthermore, in a few outcrops this lithofacies exhibits a remarkable and enigmatic surface texture as it can be seen in Fig. 4: This surface expression is only to be seen on the surfaces of the rock facing upward. Here, the surface of the rock is covered by ca. 3-5 cm round hollows that may reach depths to ca. 5-7 $\mathrm{cm}$. The hollows are divided from each other by ca. $1 \mathrm{~cm}$ thick rims and appear to be parallel aligned along crosscutting lineament directions (Fig. 4e). Similar structures but in high temperature ash-flow tuffs were described as lithophysae (hollow, bubble-like structures) from the Makwassi Formation by van der Westhuizen and De Bruiyn (2000) and interpreted as interaction between hot pyroclastic material and water saturated surface. Lithophysae are generally interpreted as spherulites (radiating arrays of crystal fibres and high-temperature 
$\left(400-700^{\circ} \mathrm{C}\right)$ devitrification structures of coherent volcanic glass) that have a central vug. They begin to grow at an early stage in the cooling history of a lava or welded ignimbrite and involve nucleation of spherulites on small vesicles. As spherulitic crystallisation proceeds, the vesicles are expanded by the exsolving volatiles (McPhie et al., 1993).

\section{Insert Figures 6 here}

The structures observed by us are developed equally on vesicular and massive lava flows and usually do not connect with each other laterally. They seem to growth from large regularly distributed depressions in the rocks surface, deep into the rock, but not to growth in the horizontal direction (laterally). No vertical or facing downwards surfaces exhibiting such texture were found. We have discarded the possibility of these structires to represent ocelli (liquid immiscibility spherules) as were described from the Westonaria Formation (above the Venterspost Formation, Klipriveiersberg Group) by Cawthorn et al., 1979 (comp. van der Westhuizen et al., 2006, their Figs 8 and 9). A possible interpretation of the structures that obviously find similar forms in high-Mg basalts interpreted as ocelli or lithophysae of the Ventersdorp lavas could be tafoni weathering that has been described from different rocks, but also from lava flows (Mustoe, 2010 and references therein).

The andesitic-dacitic volcanic facies exhibits a massive interior with vesicles increasing in number and size (up to $10 \mathrm{~cm}$ ) upward to the top. Amygdales are partly or completely infilled with secondary quartz. The volcanic lithofacies has a dark greenish-grey color and a finecrystalline, aphyric to porphyric texture.

In thin sections (Fig. 7) the andesitic-dacitic volcanic lithofacies exhibit (sample VS02) fine porphyrytic, euhedral crystals of plagioclase and K-feldspar (both up to $1 \mathrm{~mm}$ ) and clinopyroxene (most probably augite) (up to $500 \mu \mathrm{m}$ ) set in a microcrystalline matrix of mostly plagioclase (c. $200 \mu \mathrm{m}$ ) laths with subordinate ore (magnetite?) and clay minerals. Although partly altered the plagioclase still shows zonations. The crystals constituting the matrix are not aligned and are somewhat randomly distributed in the thin sections, often lying in almost $90^{\circ}$ to each other. The sample is relatively rich in vesicles that reach diameters between 1 and $2 \mathrm{~mm}$. In sample VS05 myrmekite-like textures were observed on some feldspars, which are also surrounded by a reaction rim of devitrified glassy material (Fig. 7a, b). Such textures are usually attributed to replacement reaction of K-feldspar by plagioclase. 
In some samples (VSO3) the crystals constituting the matrix are not aligned and are somewhat randomly distributed in the thin sections, often lying in almost $90^{\circ}$ to each other. Thin section is relatively rich in vesicles that reach diameters between 1 and $2 \mathrm{~mm}$. The vesicles are amoeboid-shaped and are partly infilled by microcrystaline calcite crystals or by quartz (sample VS10). The samples VS06 and VS07 exhibit a porphyritic texture with plagioclase, K-feldspar, and minor quartz phenocrysts set in a devitrified, mostly cryptocrystaline clay mineral-rich matrix containing microcrysts of feldspar needles $(50-100 \mu \mathrm{m})$ and magnetite. The phenocrysts are subhedral to euhedral, either showing a glomeroporphyritic texture with small clusters or a diffuse alignment. The quartz is partly resorbed and shows embayments and rounded outlines. Especially the glomeroporphyritic texture is usually typical for a coherent lava lava flow. Secondary calcification can bee seen in sample VSO8 from the various fine calcite crystals within the matrix.

The volcanic lithofacies, represented by andesites and dacites are interpreted to be relatively low viscosity lava flows, which in certain localities closely resemble modern day pahoehoe flows. Pahoehoe is characterized by smooth, lobate surfaces that may be buckled and folded into intricate ropy patterns (Fink and Fletcher, 1978). It forms at low volumetric flow rates and flowage in tubes from which heat loss is minimal, allowing maintenance of relatively low viscosity (McPhie et al., 1993). These flows usually comprise many small flow units (Rowland and Walker, 1990).

The enigmatic hollows on the surface of the lava flows are interpreted as tafoni or honeycomb weathering structures. Honeycomb weathering occurs in metamorphic, igneous, and sedimentary rocks at coastal and inland locations around the world, ranging from polar latitudes to the equatorial (Viles, 2005). The processes of differential erosion that give rise to tafoni structures have been a matter of great controversy, with many hypotheses having been advanced, including wind erosion, exfoliation, frost shattering, and salt weathering (Mustoe, 1982). Most recent literature explains these cavity patterns to develop when permeable rocks are exposed to solutions containing dissolved salts in environments characterized by cyclic wetting and drying. In arid regions, salt weathering commonly involves alkaline sulfates or carbonates released from rock decomposition, in combination with wetting and drying cycles that are related to dew, capillary transport of moisture through soil, or subsurface flow of moisture within permeable bedrock (Mustoe, 1983, 2010; Goudie and Viles, 1997).

\section{LFT 2: Massive ash-tuff lithofacies}


Within the study area tuff layers are exposed consisting of a massive poorly sorted mixture of accessory and accidental lithic fragments set in a matrix of fine to medium ash. Unit thicknesses range from a few centimeters to several meters. The ash-tuff facies is strongly silicified and its greenish-grey colour is evidence that it has undergone greenschist metamorphism (Fig. 8a, c). Accessory lithic clasts are comprised of granitic rocks and coarse sandstones that are evidently derived from the granitic basement and the surrounding grits, respectively. The clasts show very little signs of abrasion and exhibit an angular appearance.

In thin section (Fig. 8a, c) the massive ash-tuff lithofacies appears as a very fine-grained clastic texture with micro- to cryptocrystaline fragments of predominantly of feldspar and quartz, and minor mica, set in a matrix of clay minerals (and rare magnetite). The clay minerals originate probably through devitrification of glass shards and decomposition of feldspars and are largely choritised (samples VS11 and VS13). In other samples (VS05) phenocrysts constitute of plagioclase and K-feldspar (up to $3 \mathrm{~mm}$ ). Rare microcline is also present. Few of the phenocrysts are euhedral. Many are shattered and broken. So are the microcrystalline plagioclase and K-feldspar (sanidine) laths $(200 \mu \mathrm{m})$ that constitute the main mineral phase in the matrix. Further matrix minerals are subordinate crystals of ortho- and clinopyroxene (ca. $100 \mu \mathrm{m}$ ), magnetite and finely distributed clay minerals and calcite crystals. The latter were most probably introduced into the rock by secondary processes. Due to the broken crystals in the thin section and the therefore pyroclastic texture such samples are interpreted as a crystal tuff. Sample WA28/10 exhibits conspicuous devitrification patterns with albite crystals in the centre, surrounded by carbonatized rims which are concentrically partly silicified (Fig. 9e-h). The nests are probably altered spherulites containing quartz cores or feldspar (albite) cores that have been recrystallized to a quartz-carbonate mosaic as a result of later alteration and metamorphism. This sample is a carbonate rich, silicified very fine ash tuff with single lapilli floating in the chloritized, greenish matrix.

The massive ash-tuff lithofacies is interpreted as ash-flow deposit as described by many authors as the most common ignimbrite lithofacies (e.g. Ross and Smith, 1961; Sparks, 1976; Wilson and Walker, 1982; Branney and Kokelaar, 2002). Because of the angularity of the accessory lithic clasts a relatively short distance of transport is proposed. Very large ash flows are usually formed during Plinian eruptions of dacitic to rhyolitic magma. However, smaller volumes and travelled distances are reported from andesitic to basaltic ash flows (e.g. Robin et al., 1994; Freundt and Schmincke, 1995). 


\section{Insert Figures 7 here}

\section{LFT3: Stratified and cross-stratified tuff lithofacies}

The stratified tuff forms thin (ca. $5 \mathrm{~cm}$ in thickness) discontinuous layers, is moderately sorted, and mostly composed of a coarse ash matrix with accidental lithic fragments and altered pumice fragments of ash to lapilli size. The stratification varies from subparallel, through pinch-and-swell stratification to cross-stratified tuff, sometimes with anti-dune structures (Fig. 8). The lower surfaces can be flat, although local erosional surfaces can be recognised.

Under the microscope (Fig. 9c, d) this lithofacies consists of coarse, fragmented and devitrified tuffs with indistinct alignment of feldspar phenocrysts and volcanic fragments. Abundant feldspars ranging from $\mathrm{K}$ - feldspar and microcline to plagioclase, quartz, glas shards, chloritization is dominant, partly strongly devitrified. Feldspars are partly sericitized and carbonatitized. Carbonate is visible in interstitial space. Feldspar and quartz fragments exhibit some resorption embayments (WA32/10).

The rocks are interpreted as being deposited under surge-like depositional conditions from dilute gravity currents (Allen et al., 1999) and are interpreted as pyroclastic surge deposits. The subparallel stratification, cross-stratification, and moderate sorting indicate deposition from traction-dominated flow boundaries (Branney and Kokelaar, 2002). The subparallel stratification differs from ash-fall lamination in that individual laminae are discontinuous and the lithofacies exhibit grain fabrics (Cagnoli and Tarling, 1997).

\section{LFT4: Coarse-grained grit lithofacies}

The coarse-grained grit lithofacies is internally massive to poorly stratified and reaches thicknesses of up to few tens of meters. Individual units have flat planar contacts that are commonly sharp and non-erosive and can be up to c. $10 \mathrm{~m}$ thick. The facies has a greenishgrey to almost white matrix of coarse sand-sized to fine gravel-sized grains, consisting almost entirely of quartz and feldspar fragments. Outsized clasts up to cobble and boulder size are mostly of granitic composition and are therefore interpreted to be derived from the granitic basement directly underlying the Ventersdorp Supergroup in this location. Minor lava clasts 
are most probably derived from the surrounding Ventersdorp lava flows or from older not exposed volcanics.

Under the petrographic microscope (Fig. 2) the grits and fine conglomerates display a layered, alternating fine to coarse, poorly sorted, very angular to subrounded sandstone texture, with abundant rock fragments of crystalline rocks, abundant quartz clasts and various feldspar clasts (microcline, diverse plagioclases), sandstone fragments, large altered biotite clasts squeezed between the other clasts, some epidote grains and chlorite in the intergranular space. The feldspars are often serizitised and altered. Fe-oxide stains throughout the matrix and around the clasts is frequent. The grits are highly compacted with no visible porosity, cemented by recrystallised, plaster-textured chert, which also extends into veinlets and cracks. Some interstitial carbonate filing the pores is visible in several thin sections (WA21/10; WA23/10; WA24/10).

This lithofacies is interpreted as debris flow deposit that had only a limited turbulence and suspension fall out, due to high particle concentrations (e.g., Bandopadhyay, 2005). The dominant flow mechanisms were probably laminar and/or plug flow (Wright and Walker, 1980; Lowe, 1988). Flash flood deposits are intercalated in places.

\section{Insert Figures 8 here}

\section{LFT5: Fine-grained tuffitic sandstone lithofacies}

This facies is characterized by beds of fine- to medium-grained tuffitic sandstone, interbedded with thin mudstone, and reaching up to few $\mathrm{dm}$ in thickness. The beds are massive, or laminated or cross bedded, and some show symmetrical and asymmetrical bifurcating ripple marks (Fig. 6b, c) on bed surfaces. In this lithofacies also the thin silicified ash laminae with the raindrop imprints and desiccation polygons are present (comp. above). Conspicuous coarse grain laminae within fine matrix sandy material and with aligned and dense clast distribution within each particular clast lamina occur as well in this lithofacies.

Rare fine grained sandstone beds, especially those intercalated with pelitic intervals show a grading-upward and faint laminations in the upper part, similar to a Bouma Ta-b division. Outsized granitic fragments up to $0.5 \mathrm{~cm}$ are sometimes present, probably resembling floating clasts in turbidites (Postma et al., 1988). The grains are angular to rounded and rich in 
feldspar (arkosic). The matrix is composed of finer, largely pelitic detritus, abundant in chlorite visible in thin sections. Silicification of matrix is common but not pervasive. Post diagenetic chert veins crosscut the clasts and matrix and evidence for hydrothermal silicifcation during metamorphic and burial alteration.

In thin section the fine-grained tuffitic sandstone lithofacies is characterized by a clastic texture constituting fragments of quartz, plagioclase, microcline (including microclineperthite) and rock fragments in a very fine-grained clayey matrix. The finer fragments show a subtle alignment in the matrix. In all samples plagioclase had been altered to a certain degree to sericite and chlorite. The groundmass is probably smectite and calcite altered (samples VS15 and VS 16).

The laminated and cross bedded, rippled, fine sandstones were deposited in shallow lacustrine or fluvial environments. Desiccation polygons and rain drop or hale impact craters evidence subaerial exposure. The single lamina or thin beds of coarse clasts within finer matrix sandstones are interpreted as flash flood deposits. On the other hand, Bouma sequences indicate a turbidity current origin for some beds of the fine-grained tuffitic sandstone facies, probably deposited in a deeper and more distal lacustrine environment. The normal graded lower part is the result of deposition from suspension, whereas limited traction in combination with suspension may have produced the massive to faintly laminated upper parts of the turbidites (Lowe, 1982). Outsized floating clasts indicate existence of high-density turbulent flows (Postma et al., 1988).

\section{Insert Figure 9 here}

\section{LFT6: Tuffaceous mudstone lithofacies}

The black to dark greenish-brown tuffaceous mudstone lithofacies is characterized by up to few $\mathrm{cm}$ thick beds with generally sharp and flat bases. The beds usually follow one on top of another and can accumulate to considerable thickness of several tens of metres without coarser intercalations (as far as exposure allows for such a statement). The mudstones are massive or faintly parallel laminated and locally contain dewatering deformation structures and/ or small-scale syn-sedimentary faults, slumps and small channels. 
Petrographic study of the very fine-grained mudstones shows only clay- and silt-sized quartz and clay minerals that are most probably derived from the weathering of pyroclastic material. Chlorite is abundant in this facies and pyrite is present. In places carbonate minerals are present as well, either as recrystallized secondary subidiomorphic rhombs or in small patches and nests (Fig. 9a, b).

The tuffaceous mudstone lithofacies is interpreted to have developed in a lacustrine environment as basinal deposits formed by low-density turbidity currents. Load structures and massive bedding in mudstones imply rapid sedimentation (e.g., Bandopadhyay, 2005).

\section{LFT7: Stromatolitic lithofacies}

Stromatolitic lithofacies encompasses stratiform, tufted mats, domical and columnar stromatolites and laterally linked stratiform to columnar stromatolites with intercaleted ripple marks and capped by rippled horizons (Fig. 10) stromatolitic laminae and ripple marks (Fig. 6d) are often silicified and display weathering induced manganese oxide coating (desert varnish on surfaces exposed to the sun). The silicification is partly well preserved, early diagenetic silica, as evident from the minute quartz crystallites and well preserved particulate carbon flakes (kerogen) within the laminae. Along many laminae the chert however is recrystallized to coarser, clean chert and the carbon is squeezed between the chert crystallites of c. $10 \mu \mathrm{m}$ diameter. Nevertheless, organo-sedimentary structures like laminae and tufts are well preserved (Fig. 10d).

The facies of laterally linked pseudo-columnar stromatolites with regular linkage between the pseudo-columns and wavy laminites was interpreted by Altermann (2007) as associated with coarse tuffaceous sand, redeposited in wave agitated, lacustrine environment. The inclined columns and current rippled stromatolite tops evidence current action and the thinner, beds of domical and stratiform stromatolites are of similar but less agitated, low energy environment, all being shallow lacustrine.

\section{Insert Figure 10 here}

\section{$\underline{\text { Geochemistry }}$}

Eight volcanic samples from lava flow deposits were collected from the Ongers River, T'Kuip and Omdraaivlei Formations for chemical analysis, based on location and apparent freshness. 
All samples were analyzed for major oxides, trace elements (Rb, Ba, Sr, Pb, Th, U, Zr, Hf, Ta, $\mathrm{Y}, \mathrm{Nb}, \mathrm{Sc}, \mathrm{Cr}, \mathrm{Ni}, \mathrm{Co}, \mathrm{V}, \mathrm{Zn}, \mathrm{Cu}, \mathrm{S}$ ) and REE (Tab. 2) at the University of Cape Town (AEON EarthLAB). Due to the high but variable LOI major element analyses were recalculated to $100 \mathrm{wt} \%$ anhydrous basis for all further interpretations of the geochemical data. All $\mathrm{Fe}$ was set as $\mathrm{Fe}^{2+}$. Mg-numbers (\%) were calculated as the molar ratio of $100 \times \mathrm{Mg} /(\mathrm{Mg}+\mathrm{Fe} 2+)$ after Ragland (1989). The chemical index of alteration (CIA) was calculated as CIA $=\left[\mathrm{Al}_{2} \mathrm{O}_{3} / \mathrm{Al}_{2} \mathrm{O}_{3}+\mathrm{CaO}+\mathrm{Na}_{2} \mathrm{O}+\mathrm{K}_{2} \mathrm{O}\right] \times 100$ (Nesbitt and Young, 1982).

The new geochemical data presented in this contribution were obtained for comparison of the Sodium Group rocks to other Ventersdorp Supergroup data presented in the literature. From several tuff samples, zircons were extracted for age dating (in preparation). Our chemical analyses from two lava samples from the Ongers River Formation, two lava samples from the T' Kuip Formation and four lava samples from the Omdraaivlei Formation fit well in the range of geochemical results obtained by Condi and Crow (1988) from various Ventersdorp Formations, but specifically the Rietgat Formation.

Petrographic investigations have revealed that most samples have been subjected to varying degrees of alteration, which is also evident from their high LOI contents, ranging from 1.6 wt.\% to 5.9 wt.\% (average $3.8 \mathrm{Wt} . \%$ ). The chemical index of alteration (CIA; Nesbitt and Young, 1982) for the samples is between 52 and 64. The CIA measures the extent to which feldspars have been converted to aluminous clays. High CIA values (approaching the 90s) due to the removal of the alkali and alkaline earth elements are associated with intensive chemical weathering. Unaltered basaltic rocks normally have CIA values between 30 and 45. Illite and montmorillonite have CIA values that range between 75 and 85, indicating a less intense weathering. Kaolinite and chlorite exhibit the highest CIA values close to 100 . The CIA values for the Ventersdorp lava samples therefore indicate that the lavas were not intensely weathered (but compare above, petrography section, where sericitisation and carbonatisation of feldspars has been documented).

\section{Insert Table 2 here}

$\mathrm{Na}, \mathrm{K}, \mathrm{Ca}$, and the low-fieldstrength elements are mostly mobile and susceptible to change during alteration. Incompatible high-field-strength-elements such as $\mathrm{Ti}, \mathrm{Zr}, \mathrm{Y}, \mathrm{Nb}$ and $\mathrm{Hf}$ are considered largely immobile during low temperature alteration processes (e.g. Cox, 1995; 
Peate, 1997). Therefore, only $\mathrm{SiO}_{2}, \mathrm{MgO}$ and the elements mentioned above are used in rock classification, petrogenetic evaluation and discussions. Major and trace element data for the Omdraaivlai Formation volcanic samples are given in Table 2. Due to the alkali mobility common in Precambrian rocks, the use of a total alkalies vs. silica diagram $\left(\mathrm{SiO}_{2} \mathrm{vs}\right.$. $\mathrm{Na}_{2} \mathrm{O}+\mathrm{K}_{2} \mathrm{O}$ ) was avoided as a means to determine their magma clan. Instead, the diagram after Winchester and Floyd (1977) is used, employing the relatively immobile elements of $\mathrm{Nb}$ and $\mathrm{Y}$ plotted against $\mathrm{Zr}$ and $\mathrm{TiO}_{2}$ (Fig. 11). The lava of the Omdraaisvlai Formation is characterized by intermediate compositions as reflected by the occurrence of andesites and dacites. Mg-numbers (Mg\#) range between 48 and 50. The otherwise common silicification of lavas and tuffs in the Precambrian (Altermann, 1997) obviously affected the Sodium Group environment less, as can be seen when comparing the lava classification diagrammes in Figures 12 and 13. Only one sample plots as a rhyolite due to the high $\mathrm{SiO}_{2}$ content in Figure (12).

Harker diagrams show negative trends of $\mathrm{Al}_{2} \mathrm{O}_{3}, \mathrm{Fe}_{2} \mathrm{O}_{3}, \mathrm{MgO}$ and $\mathrm{CaO}$ with increasing silica content. The decrease in these major element oxides is consistent with the removal of earlyforming olivine, clinopyroxene and plagioclase from the cooling liquid as can be seen from the phenocrysts content in thin sections.

Insert Figures 11 to 15 here.

Chondrite normalized (after Sun and McDonough, 1989) REE diagrams are plotted for the T'Kuip, Ongers River and Omdraaivlei samples in Fig. 13. All samples show a negative Eu anomaly typical of volcanic rocks with mantle provenance, and a fairly similar pattern, closely resembling the results of Crow and Condie (1988). The Th vs. Nb ratio of Pearce (2008) (i.e., $\mathrm{Th} / \mathrm{Yb}-\mathrm{Nb} / \mathrm{Yb}$ ) was chosen to highlight the crustal contamination component (Fig. 14). Here, present-day MORB and OIB form a diagonal array with average N-MORB, E-MORB and OIB at its centre. All Ventersdorp samples are displaced to higher $\mathrm{Th} / \mathrm{Yb}$ values, i.e., plotting above the array and are therefore evidence for an interaction of the magma with continental crust on ascent, or an ancient subduction component as initially suggested by Crow and Condie (1988), but less probable in this clearly cratonic setting.

$\mathrm{Sm}-\mathrm{Nd}$ isotopic data are listed in Table 4. The Ongers Rivier Formation samples have values of ${ }^{143} \mathrm{Nd} /{ }^{144} \mathrm{Nd}$ (measured) that range from 0.511243 to 0.511413 . Values of the overlying T'Kuip and Omdraaivlei Formations are fairly similar ranging from 0.510911 to 0.511060 and 
0.510934 to 0.511352 , respectively. Values of $\mathrm{R}_{0(\mathrm{Nd})}$ calculated for the Sodium Group average 0.508514 . Calculated values $\varepsilon^{\mathrm{t}} \mathrm{Nd}$ for all of samples are all negative and range from -77.1 to -96.1 (Fig. 15).

In summary our 8 samples do not reveal any new details on the composition and provenance of the Ventersdorp and fit very well with results of previous investigations, confirming the geochemistry results by Crow and Condi (1988) and Nelson et al. (1992).

\section{Discussion and conclusions:}

Our overview of the Ventersdorp Supergroup and the comparison to the Sodium Group between Prieska and Britstown demonstrate significant similarities between these volcanosedimentary successions, as already proposed by SACS (1980), van der Westhuizen et al. (1987; 1989, 1991 and 2006 and literature cited therein). The new data presented from the Sodium Group concur with the sedimentological and volcanic setting as interpreted for the Ventersdorp Supergroup and with the rough regional correlation to the Platberg Group. Nevertheless, it becomes clear that more work is needed, but particularly precise zircon age data from both successions. Although the sedimentary facies interpretation and the geochemical data presented herein, correspond in general with the sedimentology and geochemistry of the basal Ventersdorp rocks (Venterspost Formation) up to the Platberg Group in similar facies and geotectonic setting, exact correlation is not possible. This is equally valid for the other outliers of the Ventersdorp Supergroup, like the Zoetlief or the Zeekoebaart Groups and the older Kanye Formation. Only precise age dating will allow for the evaluation of the duration of deposition of both volcano-sedimentary successions, for interformational correlations and for a valid interpretation of the geotectonic setting of the Ventersdorp Supergroup. For such an interpretation the knowledge of the lateral extend and the duration of the deposition is crucial. Investigations of the underlying manifold crystalline rocks as to their petrography, structural geology and ages, will supplement the evaluation of the Ventersdorp depositional basin by better understanding of the continental basement on which it has developed. Unfortunately until today, the Ventersdorp Supergroup research was driven by economic interests ruling the gold mining industry, and was dictated by research of the Witwatersrand basin and its cover rocks, with the exception of few publications by van der Westhuizen and his group (op. cit.) and few other researchers.

\section{Insert Figure 16 here}

The Ongers River Formation has been interpreted as basal, rift-related sedimentation on the extending and subsiding cratonic basement. Erosion of topographically pronounced graben shoulders led to a development of thick and coarse, poorly sorted alluvial fans, incised by 
braided rivers and blanketed by flash floods. Fine sediments were accumulated in distal lakes and turbidites were deposited in more proximal lacustrine environments. Fast sedimentation and high burial rates prevented deep weathering of the coarse detritus. Transport distances were short from the graben flanks to the valleys. Desiccation cracks and rain or hail impacted surfaces evidence terrestrial - volcaniclastic, exposed surfaces, fastly burried by resedimented tuff with preserved delicate structures like mud flakes an accretionary lapilli. Mafic volcanism accompanied the tectonic development and provided abundant effusive and extrusive material, that was rapidly eroded and re-sedimented. The volcanic centres must have been located along the graben boundary faults, as scoria cones, fissure- and stratovolcanoes, with extrusive and phreato-magmatic activity.

The above description fits well the general setting of the sediments and volcanics of the Venterspost Formation at the base of the Ventersdorp Supergroup, where it directly covers basement rocks (comp. Germs and Schweitzer, 1994; van der Westhuizen et al., 2006).

The T'kuip Formation lavas appear to be correlatable with the Makwassi porphyries, although a proof of such correlation has never been presented and the correlation remains circumstantial. The unconformity between the T'Kuip Formation and the underlying Ongers River Formation has not been found in our working area. The upper boundary to the Omdraaivlei Formation appears conformable and has been identified between a porphyritic and a basaltic lava flow by SACS (1980), but this could not be verified in the present work. Overall, the T'Kuip Formation marks a period of mainly extrusive intermediate to acidic volcanism without much of tectonically induced coarse sedimentation. It may reflect a postgraben volcanism, comparable to the Orkney, Loraine or Edenville Formations of the Klipriviersberg Group up to the Makwassi Formation of the Platberg Group (comp. Buck, 1980). For a better correlation, precise age data are indispensable.

In the Omdraaivlei Formation the volcanic activity turns again to mafic-intermediate. The formation is usually correlated with the upper Platberg Group (Rietgat Formation; van der Westhuizen et al., 2006). Sedimentary deposits become more abundant and are in the lower part coarse, and akin to the above described Venterspost and Ongers River gritstones and conglomerates, albeit less coarse and less thick and extensive. Thus, the volcanism and sedimentary environments seem to reflect conditions similar to the lower part of the succession, but more distal, or at a generally less pronounced topographic variation and perhaps accompanied by lesser tectonic activity. Subaerial extrusive and explosive volcanism 
with surges, ignimbrites (van der Westhuizen and Grobler, 1987) and interaction of hot lavas and ash flows with wet surface sediments (e.g. van der Westhuizen and de Bruiyn, 2000) is evident, but changes at the top of the formation to subaquatic pillow lava flows (SACS 1980). In the stratigraphic middle of the formation, shallow lakes developed where fine tuffaceous sediments were accumulated next to distal turbidites. During pronounced periods of tectonic quiescence and lack of detritus, short lived and laterally restricted stromatolitic reefs developed in these lakes and were repeatedly buried underneath fine volcaniclastic detritus. A general picture of the Sodium Group depositional facies, but emphasising the sedimentary facies over the extensive extrusive volcanism, is shown in Figure 15.

The Ventersdorp Supergroup and its outliers clearly represent the largest LIP of the Kaapvaal craton. The geotectonic setting for this LIP has not been adequately explained yet in our opinion. The sedimentary and volcanic rocks have close similarity to graben fills like for example present in the rift system reaching from the Dead Sea to the East African Rift. However, marine-oceanic realms are entirely missing, the deposition being clearly on the Kaapvaal craton basement. Also the stretch of the Ventersdorp rift system is with c. $750 \mathrm{~km}$ strike by an order of magnitude smaller. Nevertheless a scenario of a failed continental rift system, that might have been lasting for 70 myr and more, appears appealing.

Any relationship to the Limpopo and the collision between the Kaapvaal and Zimbabwe cratons remains enigmatic. A tectonic escape basin model appears unlikely, because of the geometry relationships between the basin and the belt and the lack of large lineaments with strike-slip lateral displacement. The age of the collision and metamorphism in the Limpopo belt (>3.2 to $2.0 \mathrm{Ga}$ ) does not necessarily corresponds to the Ventersdorp basin development, and is poorly constrained (Kramer et al., 2006; Rigby et al., 2008; Rigby and Armstrong, 2010; Bumby et al., in press). On the other hand, the mantle plume model as discussed by Hatton (1995), or Eriksson et al. (2002), does not explains the bimodal volcanism and the reappearance of komatiites at the top of the Ventersdorp succession. Given a choice however, we would rather lean towards the latter model, for it allows for a longer time span of basin formation and filling, explains well the lower basaltic-komatiitic to anesitic-dacitic volcanic sequence and accommodates the sedimentary facies development in a graben to half-graben setting, as described above.

\section{Acknowledgements}


The authors wish to thank the University of Pretoria and the National Research Foundation for financial support. The Council for Geosciences, Pretoria, is thanked for preparation of thin sections and cutting of the samples. All geochemical analyses were performed at the University of Cape Town. Willem van der Westhuizen has introduced W.A. to the region and its geology and to the Jackson family in 1996. Edwin Jackson and his family were excellent hosts during the fieldwork seasons in 2007-2010 and made the stay on Omdraaisvlei an unforgettable experience.

\section{References}

Allen, S.R., Stadlbauer, E., Keller, J., 1999. Stratigraphy of the Kos Plateau Tuff: product of a major Quaternary explosive rhyolithic eruption in the eastern Aegean, Greece. Int. J. Earth. Sci. 88, 132-156.

Altermann, W. 2007. Accretion, trapping and binding of sediment in Archean stromatolites morphological expression of the antiquity of life. Space Sci. Rev., 135, 55-79.

Altermann, W., 1996. Discussion of Zircon Pb-evaporation age determinations of the Oak Tree Formation, Chuniespoort Group, Transvaal Sequence: implications for the Transvaal-Griqualand West correlations. South African Journal of Geology, 99. 337-338.

Altermann, W., Nelson, D.R., 1998. Sedimentation rates basin analysis and regional correlations of three Neoarchaean and Palaeoproterozoic subbasins of the Kaapvaal Craton as implied by precise SHRIMP U-Pb zircon ages from volcanic sediments. Journal of Sedimentary Geology, 120. 225-256.

Armstrong, R.A., Compston, W., Retief, E.A., Williams, I.S., Welke, H.J., 1991. Zircon ion microprobe studies bearing on the age and evolution of the Witwatersrand triad. Precambrian Res. 53, 243-266.

Bandopadhyay, P.C., 2005. Discovery of abundant pyroclasts in the Namunagarh Grit, South Andaman: evidence for arc volcanism and active subduction during the Palaeogene in the Andaman area. J. Asian Earth Sci. 25, 95-107.

Barrett, T. J., MacLean, W.H., 1997. Stratigraphic, Lithogeochemical and Petrographic Relations of Volcanic and Associated Rocks in the Engine Zone, Parys Mountain Massive Sulphide Deposit, North Wales (with a Brief Report on the Rhosmynach Outcrop Area). Unpublished Report for Anglesey Mining plc, Bangor, Wales, 102.

Bennett, H., Oliver, G., 1992. XRF analysis of ceramics, minerals and allied materials, Wiley \& Sons, Chichester, 298.

Beukes, N.J., and Nelson, J.P., 1995. Sea-level fluctuation and basin subsidence controls on the setting of auriferous palaeoplacers in the Archaean Witwatersrand Supergroup: a genetic and sequence stratigraphic approach: Abstract volume, Centennial Geocongress, Geological Society of South Africa, Johannesburg, 860-863.

Bowen, T.B., Marsh, J.S., Bowen, M.P., Eales, H.V. 1986. Volcanic rocks of the Witwatersrand Triad, South Africa: description, classification and geochemical stratigraphy. Precambrian Res., 31, 297-324.

Branney, M.J., Kokelaar, P., 2002. Pyroclastic density currents and the sedimentation of ignimbrites. Mem. Geol. Soc. Lond. 27, 143 pp.

Brock, B.B., Pretorius, D.A., 1964. An introduction to the stratigraphy and structures of the Rand Gold Field. In: S.H. Haughton (Ed.), The geology of some ore deposits in southern Africa, 1. Geological Society of South Africa, pp. 25-61. 
Buck, S.G., 1980. Stromatolite and ooid deposits within the fluvial and lacustrine sediments of the Precambrian Ventersdorp Supergroup of South Africa. Precambrian Res., 12, 311330.

Bumby, A.J., Eriksson, P.G., Catuneanu, O., Nelson, D.R., Rigby, M.J. (in press). Mesoarchaean and Palaeo-proterozoic sedimentary sequence stratigraphy of the Kaapvaal craton. J. Marine Petrol. Geol.

Cagnoli, B., Tarling, D.H., 1997. The reliability of anisotropy of magnetic susceptibility (AMS) data as flow direction indicators in friable base surge and ignimbrite deposits: Italian examples. J. Volcan. Geotherm. Res. 75, 309-320.

Cawthorn, R.G., McIver, J.R., McCarthy, T.S., Wyatt, B.A., Ferguson, J., Barns, S.J. 1979. Possible liquid immiscibility textures in high magnesia basalts from the Ventersdorp Supergroup, South Africa. J. Geol. 87, 105-113.

Cheney, E.S., Roering, C., de la Winter, H. 1990. The Archean-Proterozoic Boundary in the Kaapvaal Province of Southern Africa.- Precambrian Res. 46, 329-340.

Clendenin, C.W., Charlesworth, E.G., Maske, S. 1988a. An early proterozoic three-stage rift system, Kaapvaal Craton, South Africa. Tectonophysics, 145, 73-96.

Clendenin, C.W., Charlesworth, E.G., Maske, S. 1988b. Tectonic style and mechanism of early Proterozoic successor basin development, southern Africa. Tectonophysics, 156, 275-291.

Coetzee, C.B., 1960. The geology of the Orange Free State Gold-Field. Mem. Geol. Surv. S. Afr., 49, 198 pp.

Corcoran, P.L. and Mueller, W.U., 2002. The effects of weathering, sorting and source composition in Archean high-relief basins: examples from the Slave Province, Northwest Territories, Canada. In W. Altermann and P.L. Corcoran (Editors), Precambrian sedimentary environments: modern approach to ancient depositional systems. Blackwell, Oxford, pp. 183-212.

Cox, P.A., 1995. The Elements on the Earth. Oxford Univ. Press, 287.

Crow, C., Condi, K.C., 1988. Geochemistry and origin of the late archean volcanics from the Ventersdorp Supergroup, South Africa. Precambrian res., 42, 19-37.

Du Toit, A.L. 1908. Geological survey of portions of Hopetown, Britstown, Prieska and Hay. $12^{\text {th }}$ Ann. Rep. Geol. Comm. Cape of Good Hope (for 1907). 161-192.

Emslie, D.P., 1972. The geology of an area around Sodium, Britstown District, Northern Cape. M. Sc. Thesis, University of the Orange Free State, Bloemfontein, 99, (unpublished).

Eriksson, P.G., Altermann, W., Catuneanu, O., van der Merwe, R., Bumby, A.J., 2001. Major influences on the evolution of the 2.67-2.1 Ga Transvaal basin, Kaapvaal craton. Sedimentary Geology 141-142, 205-231.

Eriksson, P.G., Condie, K.C., van der Westhuizen, W., van der Merwe, R, de Bruijn, H., Nelson, D.R., 2002. Late Archaean superplume events: a Kaapvaal-Pilbara perspective. Journal of Geodynamics 34, 207-247.

Fink, J.H., Fletcher, R.C., 1978. Ropy pahoehoe: surface folding of a viscous fluid. J. Volcanol. Geotherm. Res. 4, 151-170.

Floyd, P.A., Winchester, J.A., 1975. Magma type and tectonic setting discrimination using immobile elements. Earth Planet. Sci. Lett., 27, 211-218.

Freundt, A., Schmincke, H.-U., 1995. Eruption and emplacement of a basaltic welded ignimbrite during caldera formation on Gran Canaria. Bull. Volcanol. 56, 640-659.

Geological Map of South Africa 1: 250000; 3022 Britstown. 1991. Geological Survey Pretoria. Printed by the Republic of South Africa, Government Printer, Pretoria.

Germs, G.J.B., Schweitzer, J.K., 1994. A provisional model for the regional morphostratigraphy of the Venterspost Conglomerate Formation in the West Rand and Carletonville Goldfields, S. Afr. J. Geol., 97, 278-287. 
Goudie, A.S., Viles, H.A., 1997. Salt weathering hazards. John Wiley \& Sons, Chichester. $\mathrm{xi}+241$.

Goudie, A.S., Viles, H.A., 1997. Salt Weathering Hazards. John Wiley \& Sons, Chichester.

Grobler N.J. and Emslie D.P., 1976. Stromatolitic limestone and chert in the Ventersdorp Supergroup at the TKuip Hills area and surroundings, Britstown District, South Africa. Trans. Geol. Soc. S. Afr., 79 , 49-52.

Grobler, N.J., van der Westhuizen, W.A., Tordiffe, E.A.W., 1989. The Sodium Group, South Africa: Reference section for late Archaean - early Proterozoic cratonic cover sequences. Austr. J. Earth Sci., 36, 41-64.

Hall, R.C.B., 1996. The stratigraphic placement of the Venterspost Conglomerate Formation: MSc thesis, Potchefstroom University for Christian Higher Education, Potchefstroom, South Africa, $153 \mathrm{p}$.

Hamilton, G.N.G, Cooke, H.B.S., 1960. Geology for South African students, $4^{\text {th }}$ ed. Central News Agency, Johannesburg, 441 pp.

Hatton, C.J. 1995: Mantle plume origin for the Bushveld and Ventersdorp magmatic provinces. J. Afr. Erth. Sci., 21, 571-577.

Henning, L.T., Els, B.g., Mayer, J.J., 1994. The Ventersdorp contact placer at Western Deep Levels South Gold Mine - an ancient terrace fluvial system. S. Afr. J. Geol., 97, 308-318.

Kerrich, R., Wyman, D.A., 1996. The trace element systematics of igneous rocks in mineral exploration: an overview. In: Wyman, D.A., Editor, , 1996. Trace Element Geochemistry of Volcanic Rocks: Applications for Massive Sulphide ExplorationShort Course Notes vol. 12, Geology Association of Canada, 1-50.

Kramers, J.D., McCourt, S., van Reenen, D.D. 2006. The Limpopo Belt. In: Johnson, M.R., Anhaeusser, C.R., Thomas, R.J. (Eds.): The Geology of South Africa. Geological Society of South Africa Johannesburg and the Council for Geoscience Pretoria. 209-236.

Linton, P. L., McCarthy, T. S., Meyers, R. E., 1990. A geochemical reappraisal of the stratigraphy of the Klipriviersberg Group in the type borehole LL1 in the Bothaville area. S. Afr. J. Geol., 93, 239-244.

Logan, B.W., Rezak, R. and Ginsburg, R.N., 1964. Classification and environmental significance of algal stromatolites. J. Geol., 72: 68-83.

Lowe, D.R., 1982. Sediment gravity flows II. Depositional models with special reference to the deposits of high-density turbidity current. Jour. Sed. Pet. 42, 775-793.

Lowe, D.R., 1988. Suspended-load fall out rate as an independent variable in the analysis of current structures. Sedimentology 35, 765-776.

Maphalala, R.M., and Kröner, A., 1993. Pb-Pb single zircon ages for the Younger Archaean granitoids of Swaziland: Abstracts, 16th Colloquium on African Geology, Geological Society of Africa, Mbabane, Swaziland 2, 201-206.

Marsh, J.S., Bowen, M.P., Rogers, N.W., Bowen, T.B. 1992. Petrogenesis of late Archean flood-type basic lavas from the Klipriviersberg Group, Ventersdorp Suprgroup, South Africa. J. Petrol., 33, 817-847.

McCourt, S., Hilliard, P. and Armstrong, R.A., 2000. SHRIMP U-Pb zircon geochronology of granitoids from the western margin of the Kaapvaal Craton: implications for crustal evolution in the Noarchean. J. Afr. Earth Sci., 31 (1A), p.48.

McPhie, J., Doyle, M., Allen, R., 1993. Volcanic textures - A guide to the interpretation of textures in volcanic rocks. Centre for Ore Deposit and Exploration Studies, University of Tasmania, Hobart, pp. 197.

Mustoe, G.E., 1982. The origin of honeycomb weathering. Geol. Soc. Am. Bull. 93, 108-115.

Mustoe, G.E., 1983. Cavernous weathering in the Capitol Reef Desert. Earth Surf. Process. Landforms 8, 517-526.

Mustoe, G.E., 2010. Biogenic origin of coastal honeycomb weathering. Earth Surf. Process. Landforms 35, 424-434. 
Nel, L.T., Jansen, H., 1958. The geology of the country around Vereeniging. An explanation of sheet 62 (Vereeniging). Geol. Surv. S. Afr., 90 pp.

Nelson, D.R., Trendall, A.F., de Laeter, J.R., Grobler, N.J., Fletcher, I.R. 1992. A comparative studies of the geochemical and isotopic systematics of late Archean flood basalts from the Pilbara and Kaapvaal Cratons.- Precambrian Res., 54, 231-256.

Nesbitt, H.W., Young, G.M., 1982. Early Proterozoic climates and plate motions inferred from major element chemistry of lutites. Nature, 299, 715-717.

Olsson, J.R., Söderlund, U., Klausen, M.B., and Ernst, R.E., in press. U-Pb baddeleyite ages of major Archean dyke swarms and the Bushveld Complex, Kaapvaal Craton (South Africa); correlations to volcanic rift forming events. Precambrian Research.

Pearce, J.A., 2008. Geochemical fingerprinting of oceanic basalts with applications to ophiolite classification and the search for Archean oceanic crust. Lithos 100, 14-48.

Peate, D.W., 1997. The Parana-Etendeka province. In: J. Mahoney and M. Coffin, Editors, Large Igneous Provinces: Continental, Oceanic, and Planetary Flood Volcanism, Geophysical Monograph, American Geophysical Union 100 (1997), 217-245.

Postma, G., Nemec, W., Kleinspehn, K.L., 1988. Large floating clasts in turbidites a mechanism for their emplacement. Sed. Geol. 58, 47-61.

Poujol, M., Kiefer, R., Robb, L.J., Anhaeusser, C.R., Armstrong, R.A. 2005. New U-Pb data on zircons from the Amalia greenstone belt, southern Africa: insights to the Neoarchean evolution of the Kaapvaal Craton. S. Afr. J. Geol., 108, 317-332.

Pretorius, D.A., 1976. The nature of the Witwatersrand gold-uranium deposits. In: K.H. Wolf (Ed.), Handbook on stratabound and strataform ore deposits, 7. Elsevier, Amsterdam, pp. 29-88.

Ragland, P.C., 1989. Basic Analytical Petrology. Oxford Univ. Press. 369 pp.

Rigby, M.J., Armstrong, R.A., 2010. SHRIMP dating of titanite from metasyenites in the Central Zone of the Limpopo Belt, South Africa. J. Afr. Earth Sci. (2010), doi:10.1016/j.jafrearsci.2010.07.004

Rigby, M.J., Mouri, H., and Brandl, G., 2008a. A review of the P-T-t evolution of the Limpopo Belt: constraints for a tectonic model: Journal of African Earth Sciences 50, 120-132.

Robin, C., Eissen, J.-P., Monzier, M., 1994. Ignimbrites of basaltic andesite and andesite compositions from Tanna, New Hebrides Arc. Bull. Volcanol. 56, 10-22.

Rogers, W.A. 1906. Geological Survey of parts of Hay and Prieska, with some notes on Herbert and Barkley West. 10 ${ }^{\text {th }}$ Ann. Rep. Geol. Comm. Cape of Good Hope. (for 1905), 141-204.

Ross, C.S., Smith, R.L., 1961. Ash-flow tuffs. Their origin, Geological Relations and Identification. U.S. Geol. Survey Prof. Pap. 366, 81 pp.

Rowland, S.K., Walker, G.P.L., 1990. Pahoehoe and aa in Hawaii: volumetric flow rate controls the lava structure. Bull. Volcanol. 52, 615-628.

SACS - South African Committee for Stratigraphy, 1980. Stratigraphy of South Africa, Part 1: Lithostratigraphy of the Republic of South Africa, South West Africa/ Namibia and the Republics of Bophuthatswana, Transkei and Venda. Handb. Geol. Surv. S. Afr., 8, 690 pp.

Sparks, R.S.J., 1976. Grain size variations in ignimbrites and implications for the transport of pyroclastic flows. Sedimentology 23, 147-188.

Sun, S. S., McDonough, W. F., 1989. Chemical and isotopic systematics of oceanic basalts: implications for mantle composition and processes. Geological Society, London, Special Publications, 42, 313-345.

Tankard, A.J., Jackson, M.P.A., Eriksson, K.A., Hobday, D.K., Hunter, D.R., Minter, W.E.L., 1982. Crustal evolution of southern Africa. Springer, Berlin, 523 pp. 
Van der Westhuizen, W.A., de Bruiyn, H. 2000. High temperature ash flow - wet sediment interaction in the Makwassi Formation, Ventersdorp Supergroup, South Africa. Precambrian Res., 101, 341-345.

Van der Westhuizen, W.A., de Bruiyn, H., Meintjes, P.G., 1991. The Ventersdorp Supergroup: an overview. J. Afr. Earth Sci., 13, 83-105.

Van der Westhuizen, W.A., de Bruiyn, H., Meintjes, P.G., 2006. The Ventersdorp Supergroup. In: Johnson, M.R., Anhaeusser, C.R., Thomas, R.J. (Eds.): The Geology of South Africa. Geological Society of South Africa Johannesburg and the Council for Geoscience Pretoria. 187-208.

Van der Westhuizen, W.A., Grobler, N.J. 1987. Ignimbrites from the Sodium Group, in the Britstown area. Workshop on pyroclastic volcanism and associated deposits. Abstr. Univ. Natal, Pietermaritzburg. 24pp.

Van Der Westhuizen, W.A., Grobler, N.J., Loock, J.C., Tordiffe E.A.W., 1989. Raindrop imprints in the Late Archaean-Early Proterozoic Ventersdorp Supergroup, South Africa. Sedimentary Geology, 61, 303-309.

Van der Westhuizen, W.A., Grobler, N.J., Tordiff, E.A.W. 1989. Raindrop imprints in the late Archaean - Early Proterozoic Ventersdorp Supergroup, South Africa. Precambrian Res.., 101, 341-351.

Van Niekerk C.B., Burger, A.J. 1978. A new age for the Ventersdorp. Trans. Geo. Soc. S. Afr., 72, 37-45.

Viles, H.A., 2005. Self-organized or disorganized? Towards a general explanation of cavernous weathering. Earth Surf. Process. Landforms 30, 1471-1473.

Visser, D.J.L., 1989. Explanation of the 1:1 000000 geological map, fourth edition, 1984: The geology of the Republics of South Africa, Transkei, Bophuthatswana, Venda, and Ciskei and the kingdoms of Lesotho and Swaziland. Geological Survey Pretoria, xiv, 491.

Walraven , F., Grobler, D.F., 1996. Age equivalence of the Plantation Porphyry and the Kanye Volcanic Formation, southeastern Botswana. S. Afr. J. Geol., 99, 23-31.

Walraven, F., Martini, J., 1995. Zircon Pb-evaporation age determinations of the Oak Tree Formation, Chuniespoort Group, Transvaal sequence: implications for TransvaalGriqualand West basin correlations. South African Journal of Geology 98, 58-67.

Walraven, F., Smith, C.B. and Kruger, F.J., 1991. Age determinations of the Zoetlief GroupVentersdorp Supergroup correlatives. South African Journal of Geology 94, 220-227.

Watson, E.B., 1996. Dissolution, growth and survival of zircons during crustal fusion: Kinetic principles, geologic models and implications for isotopic inheritance. Royal Society of Edinburgh Transactions, 87, 43-56.

Wilson, C.J.N., Walker, G.P.L., 1982. Ignimbrite depositional facies: the anatomy of a pyroclastic flow. J. Geol. Soc. Lond. 139, 581-592.

Winchester, J.A., Floyd, P.A., 1977. Geochemical discrimination of different magma series and their differentiation products using immobile elements. Chem. Geol., 20, 325-343.

Winter, H. de la R. 1965. The stratigraphy of the Ventersdorp System in the Bothaville District and adjoining areas. PhD Thesis (unpubl.), Univ. Witwatersrand, Johannesburg, 130pp.

Winter, H. de la R., 1976. A lithostratigraphic classification of the Ventersdorp succession. Trans. Geol. Soc. S. Afr., 79, 31-48.

Winter, H. de la R., 1987. A cratonic foreland model for Witwatersrand basin development in a continental back-arc, plate-tectonic setting. S. Afr. J. Geol., 90, 409-427.

Wright, J.V., Walker, G.P.L., 1980. Eruption, transport and deposition of ignimbrite: a case study from Mexico. J. Volcanol. Geotherm. Res. 8, 123-134. 


\section{Figure captions:}

\section{Figure 1}

Distribution of the outcrops and subsurface limits of the Ventersdorp Supergroup on the Kaapvaal craton. The NE-SW strike of the basin and the approximate strike of the Limpopo belt are nearly perpendicular to each other.

\section{Figure 2}

Lithofacies of grit sandtones and conglomerates: Micrographs A, B and C, D show examples of siliciclastics deposits (A and C under crossed Nicols). Rounded to angular clasts of different rocks fragments, feldspars and quartz are visible in cherty and clay matrix. Recrystallised, plaster-textured chert veinlet, crosscutting matrix and clasts is visible in A, B. Large altered biotite clast squeezed between the matrix is visible in $\mathrm{C}$ and $\mathrm{D}$ (centre). Overall composition implies deposition from eroded basement rocks, which can also be seen from the large clasts composition in the conglomerates in $\mathrm{E}$ and F, displaying basalt, schist and abundant granitic clasts.

\section{Figure 3}

Mud cracks and raindrop imprints in the Ongers River Formation. A and B show different surfaces with different density and sizes of imprints. In A (enlargement shown in G) large impact craters of considerable depth are visible. The craters are up to $1 \mathrm{~cm}$ in diameter and like the one in the right side centre, in $\mathrm{G}$, can show overprint by subsequent smaller imprints. The crater in the centre of $G$ shows overturned, radially cracked rims evidencing strong impact, probably by a hail grain. $\mathrm{E}, \mathrm{H}$ and $\mathrm{I}$ show single, small raindrop imprints, superimposed on each other in I. C, D and F exhibit saucer-shaped polygonal mud cracks and mud flakes originated from such mud cracks.

\section{Figure 4}

Different lithological features as expressed by the andesitic-dacitic volcanic lithofacies: (A) the upper surface of a lava flow, folded into ropy patterns, closely resembling the surface of modern day pahoehoe flows. (B) flow banding, typical for intermediate to silicic, more viscous lava flows (formed in response to laminar flowage), juxtaposed to isolated and coalesced spherical spherulites (up to $1 \mathrm{~cm}$ across) and locally arranged in trains that help to define flow bands. (C) "spongy", very vesicular interior of a lava flow. In modern day S-type 
(spongy) pahoehoe the abundance of vesicles is interpreted as closely reflecting the vesicle population at the time of eruption (McPhie et al., 1993). (D) interior of a lava flow rich in quartz filled amygdales. (E-F) round hollows that were interpreted as tafoni or honeycomb weathering structures and are aligned along perpendicularly crosscutting lineaments (dashed white lines in D).

\section{Figure 5}

Section measured with a Jacob's staff through the middle Omdraaivlei Formation. For facies description and interpretation see text. The middle part of the section reflects lacustrine deposits with several stromatolitic carbonate and chert horizons.

\section{Figure 6}

Examples of shallow water symmetrical and asymmetrical ripple marks (Omdraaivlei Fm.). A, C and D, symmetrical, wave ripples, chevron-type in A, where they are consolidated by microbial mats. The mats are silicified as in $\mathrm{D}$, where small water ponds in the ripple troughs left $\mathrm{ft}$ their outline marks, evidencing almost desiccation of the environment. The ripple marks in D directly cover one of the stromatolitic carbonate beds. In B, asymmetrical, current ripples with bifurcation patterns are shown as an imprint on the bottom of the superimposed sandstone bed.

\section{Figure 7}

Examples for thin-sections from lava samples in polarised (left row) and non-polarized (right row) light: (A-B) myrmekite-like texture on feldspar, surrounded by a reaction rim of devitrified glassy material. (C-D) amoeboid-shaped vesicle, partly filled by quartz crystals. (E-F) diffuse alignment of phenocrysts parallel to the flow direction (approximately N-S).

\section{Figure 8}

Examples of tuff facies. A and B, resedimented tuffs (tuffites) with accretionary lapilli. C massive tuff with intercalated surge deposit, enlarged in D. E shows a redeposited tuff with streaks of large feldspar and quartz fragments and an indistinct grading and $\mathrm{F}$ a crystal tuff with fragmented feldspars and dark, glassy devitrified shards and vesicles.

\section{Figure 9}


Microphotographs of tuff facies. A, C, E and G at crossed Nicols. A and B show a massive fine ash tuff with nests of alteration to carbonate. C and D show different devitrifed and chloritized lapilli and crystal fragments with resorption embayments (centre of $\mathrm{C}$ ). $\mathrm{E}$ to $\mathrm{H}$ exhibit spherulitic devitrification textures around albite and quarts crystals, as described in the text.

\section{Figure 10}

Examples of stromatolitic facies in the Omdraaivlei Formation. A and B show examples of partly silicified domical to irregular columnar, laterally linked stromatolites. In C, an almost completely silicified, pseudocolumnar, laterally linked stromatolite is displayed. This mat growths from a stratiform mat visible in the lower quarter of the photograph. D is a photomicrograph of a stratiform tufted mat with strongly recrystallized (pale, large crystallites) lamina and less recrystallized, primary, carbon rich, dark chert laminae (parallel Nicols).

\section{Figure 11}

Classification of volcanic rocks from the Omdraaivlei Fm., in comparison with data from the comparable Rietgat Fm. and the Ventersdorp Supergroup volcanics as a whole. Data for the comparison were taken from Crow and Condie (1988).

\section{Figure 12}

Geochemical classification of the Omdraaivlai Formation volcanics. Compositional field boundaries are according to Winchester and Floyd (1977).

\section{Figure 13}

REE of the analysed samples normalized to primordial mantle composition, after Sun and McDonough (1989). All samples show a negative Eu anomaly typical of volcanic rocks with mantle provenance, and a similar pattern, closely resembling the results of Crow and Condie (1988).

\section{Figure 14}

$\mathrm{Th} / \mathrm{Yb}-\mathrm{Nb} / \mathrm{Yb}$ ratio of Pearce (2008) highlights the crustal contamination component. All Ventersdorp samples plot above the MORB-OIB array and evidence an interaction of the 
magma with continental crust on ascent, or an ancient subduction component as initially suggested by Crow and Condie (1988).

\section{Figure 15}

(a) Plot of $\varepsilon t S r$ vs. $\varepsilon t N d$ for samples of volcanic rocks of the Ongers Rivier, T'Kuip and Omdraaivlei Formations. Calculations were made for $t=2739$ Ma. (b) Expanded plot of the right-hand portion of (a). Data are from Table 3 and Table 4.

\section{Figure 16}

Depositional model for the Sodium Group, emphasizing the sedimentary environments (Klipriviersberg and Omdraaivlei Formations) of a half-graben related setting. The model is equally applicable to the Ventersdorp Supergroup volcano-sedimentary succession. For details, see discussion in the text. 
Figures and tables

Table 1. Generalised lithostratigraphic column of the Ventersdorp Supergroup (from Armstrong et al., 1991).

\begin{tabular}{|c|c|c|c|c|}
\hline \multirow{12}{*}{$\begin{array}{l}\text { Ventersdorp } \\
\text { Supergroup }\end{array}$} & Group & Formation & Lithology & Age (Ma) \\
\hline & \multirow[t]{2}{*}{ Pniel } & Allanridge & Andesitic lava & \\
\hline & & Bothaville & Sediments & \\
\hline & \multirow{4}{*}{ Platberg } & Rietgat & $\begin{array}{l}\text { Lava and } \\
\text { sediments }\end{array}$ & \multirow{4}{*}{$2709 \pm 4$} \\
\hline & & Makwassie & $\begin{array}{l}\text { Quartz feldspar } \\
\text { porphyry }\end{array}$ & \\
\hline & & Goedgenoeg & Andesitic lava & \\
\hline & & Kameeldorings & Sediments & \\
\hline & \multirow{5}{*}{ Klipriviersberg } & Edenville & \multirow{3}{*}{$\begin{array}{l}\text { Amydaloidal and } \\
\text { porphyritic lavas } \\
\text { with subordinate } \\
\text { tuffs }\end{array}$} & \multirow{5}{*}{$2714 \pm 8$} \\
\hline & & Loraine & & \\
\hline & & Orkney & & \\
\hline & & Alberton & \multirow{2}{*}{$\begin{array}{l}\text { Quartzite and } \\
\text { conglomerate }\end{array}$} & \\
\hline & & Venterspost & & \\
\hline
\end{tabular}


Table 2. Major and trace element data for the Omdraaivlai Formation samples.

\begin{tabular}{|c|c|c|c|c|c|c|c|c|}
\hline & T'Kuip & T'Kuip & T'Kuip & Omdraaisvlei & Omdraaisvlei & Omdraaisvlei & Omdraaisvlei & $\begin{array}{l}\text { Ongers } \\
\text { Rivier }\end{array}$ \\
\hline & VS-04 & VS-05 & VS-15 & VS-07 & VS-08 & VS-10 & VS-12 & WA-28/10 \\
\hline $\mathrm{SiO}_{2}$ & 56.14 & 61.75 & 56.10 & 63.35 & 61.67 & 57.02 & 53.78 & 73.98 \\
\hline $\mathrm{Al}_{2} \mathrm{O}_{3}$ & 15.18 & 13.49 & 12.96 & 13.10 & 13.29 & 13.96 & 13.75 & 11.86 \\
\hline $\mathrm{Fe}_{2} \mathrm{O}_{3}(\mathrm{t})$ & 8.77 & 7.90 & 9.59 & 6.54 & 4.14 & 9.15 & 11.55 & 3.90 \\
\hline $\mathrm{MgO}$ & 4.08 & 2.00 & 4.93 & 2.44 & 1.48 & 3.38 & 5.10 & 1.14 \\
\hline $\mathrm{CaO}$ & 6.41 & 3.59 & 4.52 & 3.56 & 5.97 & 4.45 & 3.90 & 0.28 \\
\hline $\mathrm{Na}_{2} \mathrm{O}$ & 3.59 & 3.79 & 2.33 & 3.74 & 4.41 & 3.56 & 3.66 & 0.48 \\
\hline $\mathrm{K}_{2} \mathrm{O}$ & 1.60 & 2.15 & 1.46 & 1.55 & 2.10 & 1.53 & 0.17 & 5.86 \\
\hline $\mathrm{TiO}_{2}$ & 0.92 & 1.33 & 1.05 & 1.30 & 1.33 & 1.41 & 1.65 & 0.46 \\
\hline $\mathrm{P}_{2} \mathrm{O}_{5}$ & 0.33 & 0.59 & 0.17 & 0.54 & 0.55 & 0.60 & 0.76 & 0.06 \\
\hline $\mathrm{MnO}$ & 0.13 & 0.11 & 0.16 & 0.05 & 0.05 & 0.15 & 0.16 & 0.02 \\
\hline $\mathrm{H}_{2} \mathrm{O}-$ & 0.08 & 0.10 & 0.07 & 0.08 & 0.05 & 0.06 & 0.07 & 0.05 \\
\hline LOI & 2.45 & 3.13 & 5.89 & 3.42 & 4.47 & 4.57 & 4.67 & 1.64 \\
\hline $\mathrm{Rb}$ & 44.08 & 50.15 & 50.45 & 53.69 & 55.54 & 37.96 & 8.92 & 155.76 \\
\hline $\mathrm{Ba}$ & 1323.9 & 1316.9 & 501.8 & 806.3 & 871.4 & 1663.8 & 595.5 & 1526.4 \\
\hline $\mathrm{Sr}$ & 488.13 & 232.65 & 171.81 & 139.22 & 207.50 & 320.66 & 208.19 & 42.18 \\
\hline $\mathrm{Pb}$ & 8.65 & 33.38 & 96.34 & 2.69 & 1.90 & 4.00 & 79.19 & 2.95 \\
\hline Th & 1.51 & 5.25 & 4.26 & 5.49 & 5.57 & 2.87 & 1.03 & 6.90 \\
\hline $\mathrm{U}$ & 0.25 & 0.68 & 0.66 & 0.98 & 0.74 & 0.40 & 0.21 & 1.94 \\
\hline $\mathrm{Zr}$ & 200.32 & 429.96 & 145.07 & 433.65 & 429.49 & 340.85 & 242.64 & 397.07 \\
\hline $\mathrm{Hf}$ & 2.60 & 8.02 & 2.64 & 7.86 & 8.69 & 5.47 & 4.34 & 9.03 \\
\hline $\mathrm{Ta}$ & 0.36 & 0.76 & 0.43 & 0.77 & 0.77 & 0.64 & 0.49 & 0.97 \\
\hline$Y$ & 32.79 & 53.25 & 33.30 & 53.28 & 52.95 & 50.79 & 50.47 & 34.73 \\
\hline $\mathrm{Nb}$ & 11.17 & 20.54 & 6.47 & 19.50 & 20.85 & 17.90 & 11.96 & 18.64 \\
\hline Sc & 24.34 & 19.94 & 27.20 & 17.05 & 17.50 & 23.13 & 31.81 & 6.21 \\
\hline $\mathrm{Cr}$ & 128.51 & 62.66 & 117.59 & 46.39 & 51.71 & 190.71 & 421.60 & 24.99 \\
\hline $\mathrm{Ni}$ & 106.45 & 30.11 & 71.72 & 24.48 & 21.40 & 73.58 & 138.78 & 20.52 \\
\hline Co & 32.47 & 19.54 & 39.78 & 14.75 & 6.91 & 29.89 & 51.09 & 0.41 \\
\hline $\mathbf{V}$ & 160.08 & 153.36 & 202.69 & 151.84 & 142.48 & 207.29 & 309.19 & 26.45 \\
\hline $\mathrm{Zn}$ & 80.91 & 129.87 & 202.24 & 60.78 & 41.34 & 108.86 & 266.10 & 33.65 \\
\hline $\mathrm{Cu}$ & 53.52 & 10.13 & 235.65 & 7.16 & 3.08 & 30.45 & 51.33 & 5.01 \\
\hline $\mathrm{S}$ & 118.46 & 80.15 & 81.96 & 8.43 & 5.18 & 87.38 & 83.16 & 14.37 \\
\hline $\mathrm{La}$ & 40.22 & 76.48 & 28.22 & 73.38 & 41.50 & 72.72 & 50.75 & 21.38 \\
\hline $\mathrm{Ce}$ & 81.29 & 162.80 & 56.99 & 163.50 & 89.55 & 152.00 & 112.60 & 45.74 \\
\hline $\mathrm{Pr}$ & 10.08 & 19.20 & 6.92 & 19.14 & 12.04 & 17.76 & 14.34 & 5.69 \\
\hline $\mathrm{Nd}$ & 35.34 & 64.08 & 23.21 & 64.08 & 44.76 & 60.97 & 52.43 & 18.27 \\
\hline $\mathrm{Sm}$ & 8.21 & 13.47 & 5.84 & 13.25 & 11.30 & 13.55 & 11.77 & 5.93 \\
\hline Eu & 2.23 & 2.67 & 1.43 & 2.83 & 2.19 & 3.38 & 3.37 & 1.35 \\
\hline$G d$ & 7.93 & 12.98 & 6.65 & 13.58 & 12.16 & 13.60 & 13.01 & 5.60 \\
\hline $\mathrm{Tb}$ & 1.16 & 1.87 & 1.11 & 1.99 & 1.82 & 1.93 & 1.89 & 0.95 \\
\hline Dy & 5.33 & 8.32 & 6.03 & 9.01 & 9.02 & 8.52 & 8.71 & 5.33 \\
\hline Ho & 1.07 & 1.69 & 1.24 & 1.78 & 1.80 & 1.69 & 1.73 & 1.16 \\
\hline $\mathrm{Er}$ & 3.06 & 4.95 & 3.48 & 5.30 & 5.16 & 4.91 & 5.04 & 3.58 \\
\hline $\mathrm{Tm}$ & 0.39 & 0.63 & 0.48 & 0.67 & 0.69 & 0.60 & 0.64 & 0.52 \\
\hline $\mathrm{Yb}$ & 2.44 & 4.10 & 2.90 & 4.33 & 4.42 & 3.81 & 4.03 & 3.42 \\
\hline Lu & 0.32 & 0.60 & 0.43 & 0.62 & 0.66 & 0.54 & 0.59 & 0.53 \\
\hline $\mathrm{Eu} / \mathrm{Eu}^{*}$ & 0.85 & 0.62 & 0.70 & 0.64 & 0.57 & 0.76 & 0.83 & 0.72 \\
\hline $\mathrm{FeO}(\mathrm{t})$ & 7.90 & 7.11 & 8.64 & 5.89 & 3.73 & 8.25 & 10.41 & 3.52 \\
\hline Mg\# & 47.98 & 33.43 & 50.45 & 42.53 & 41.53 & 42.22 & 46.67 & 36.65 \\
\hline
\end{tabular}




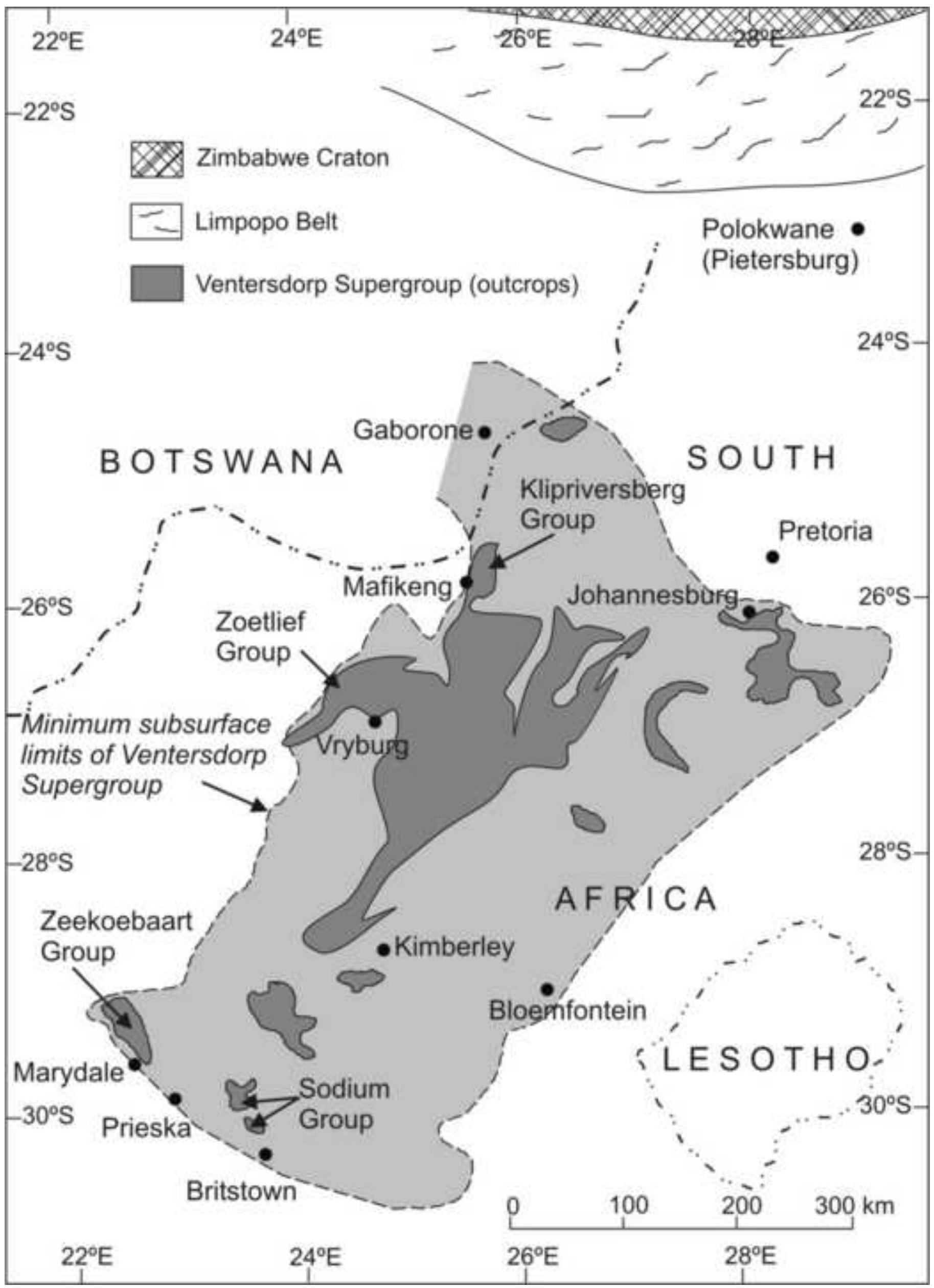



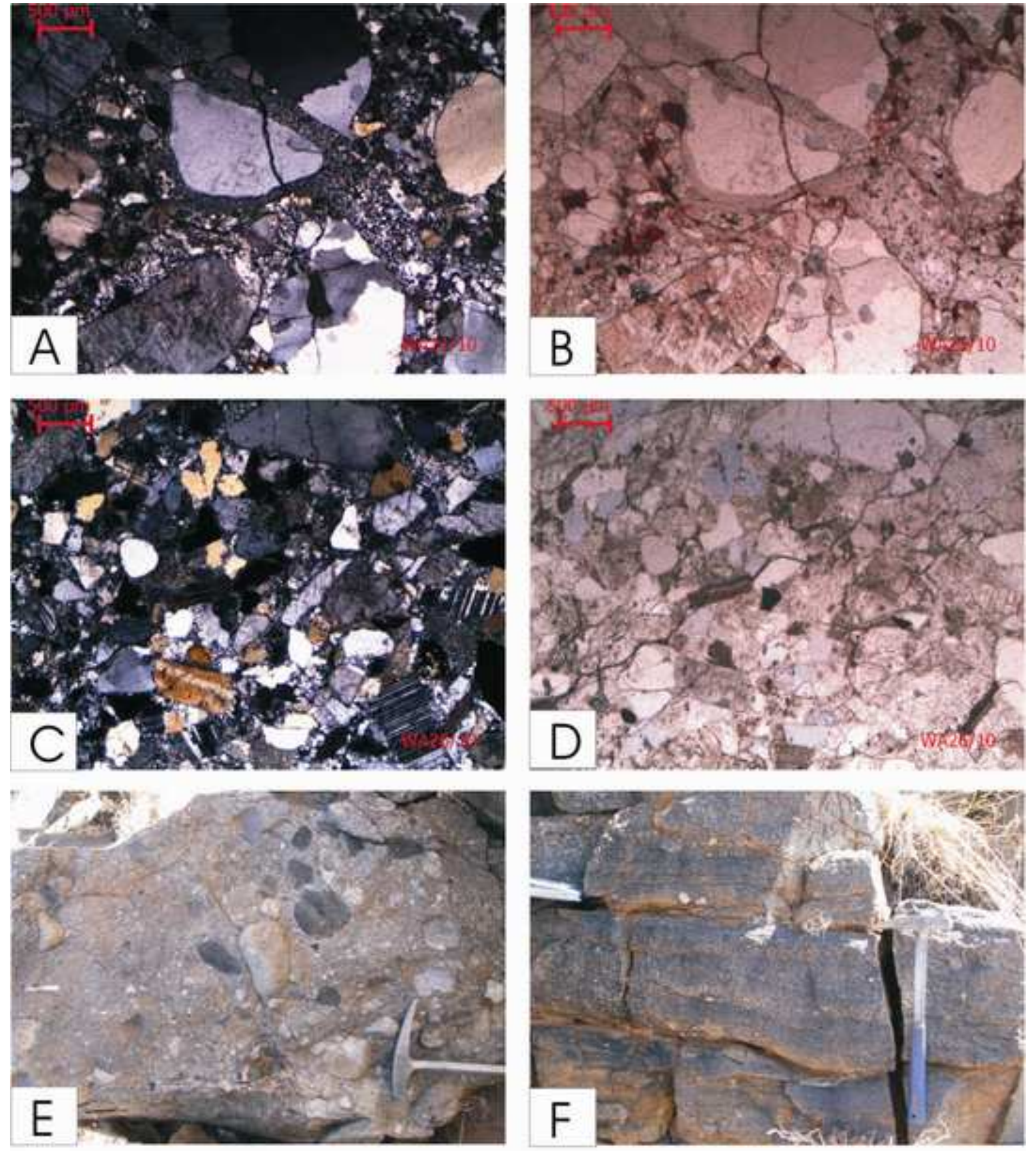

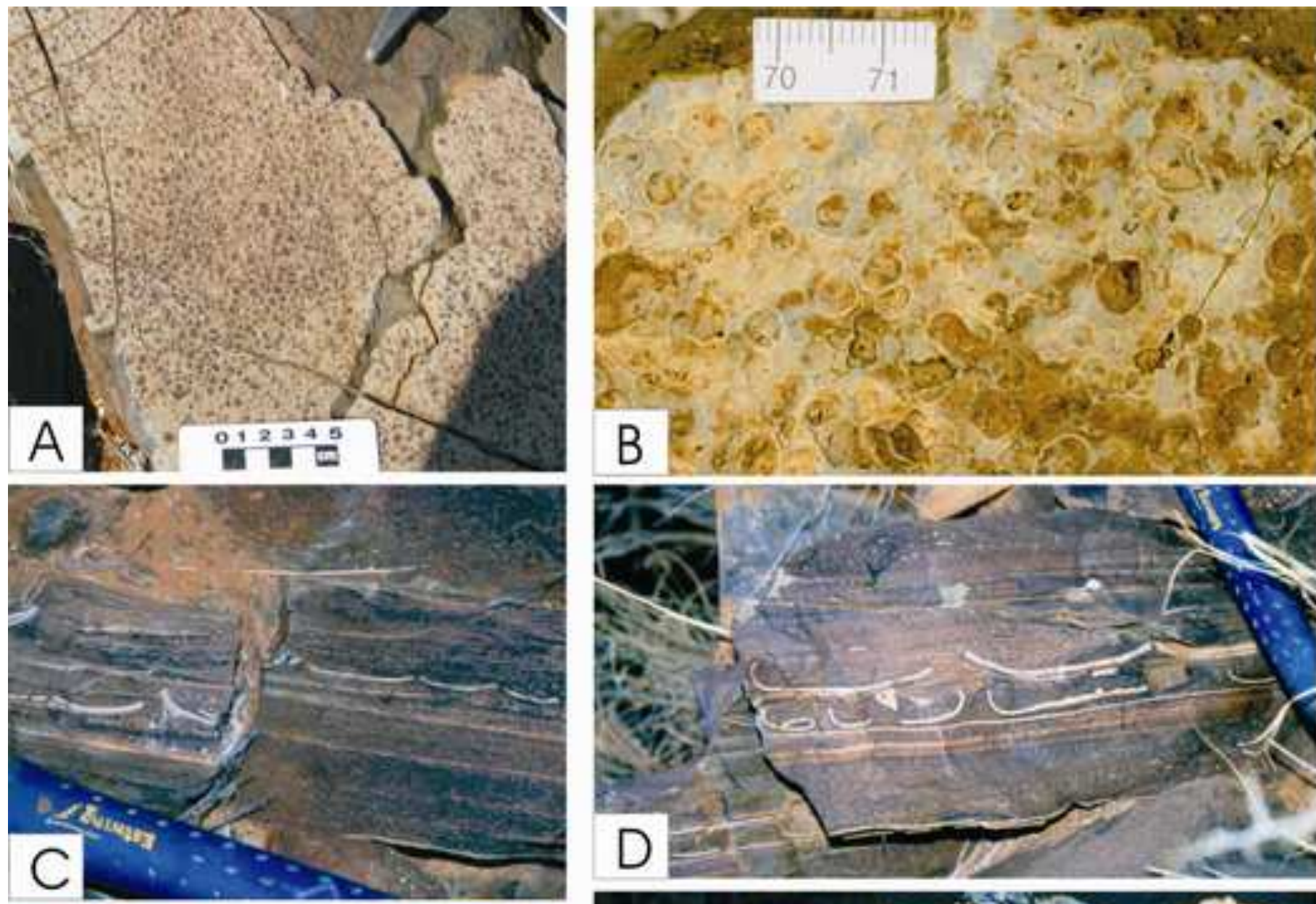

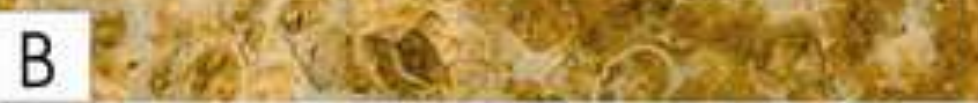
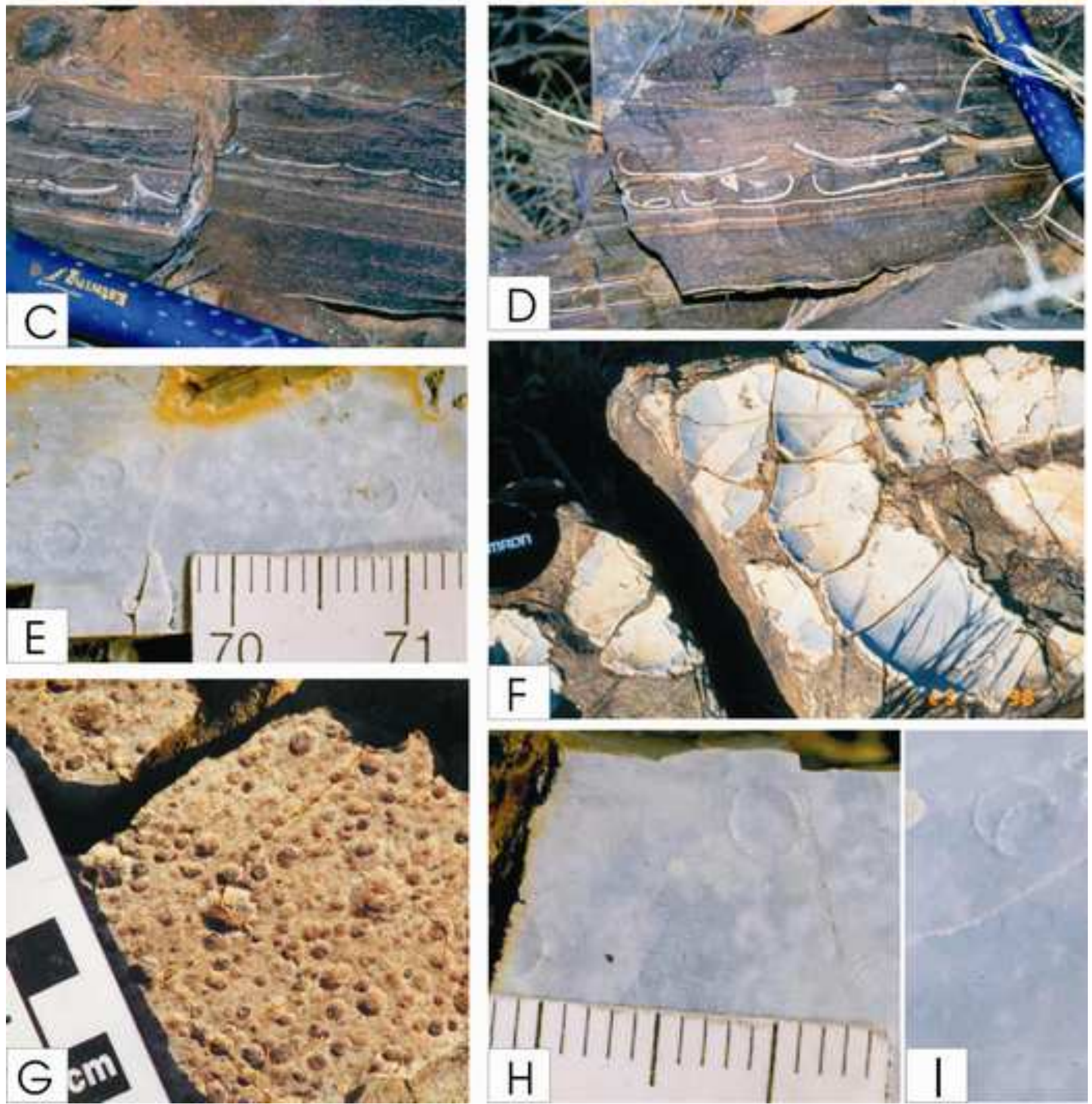

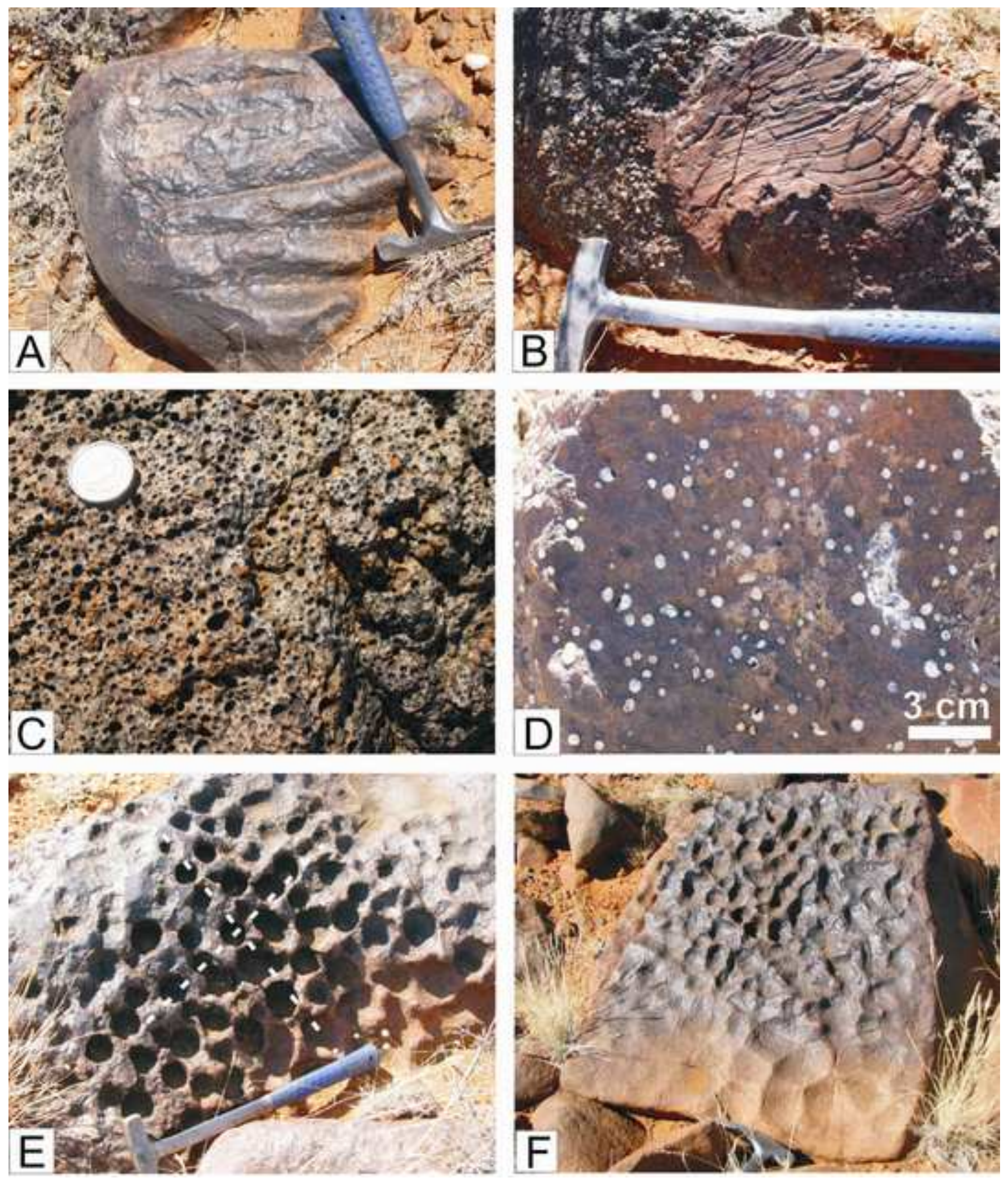
Figure 5

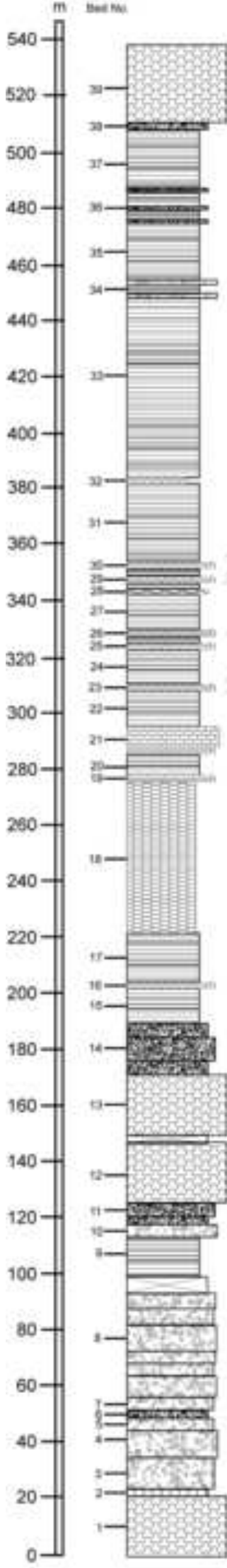

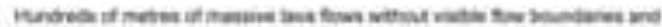

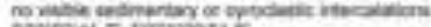

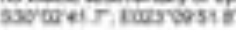

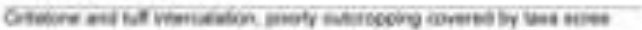

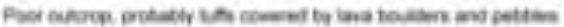

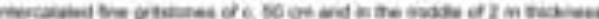

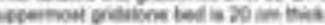

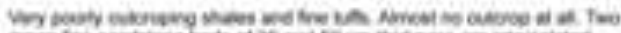

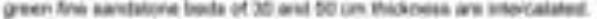

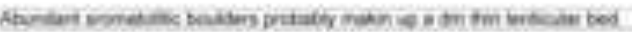

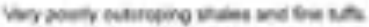

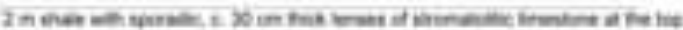

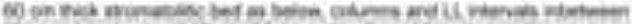

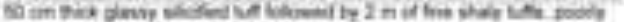

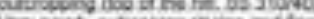

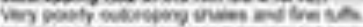

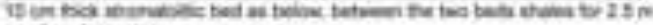

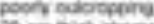

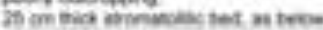

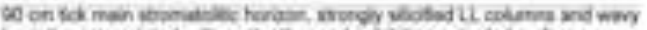

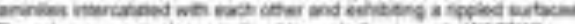

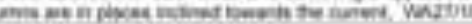

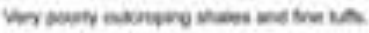

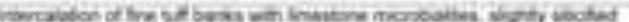

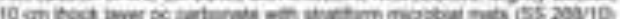

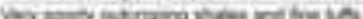

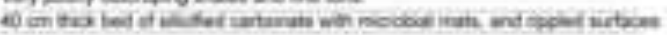

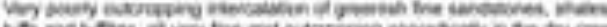

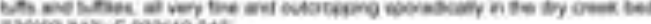

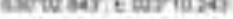

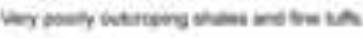

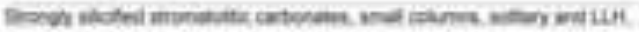

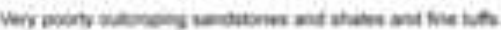

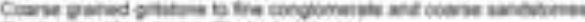

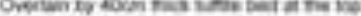
Sarcis Wu, sero

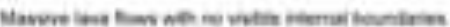

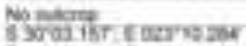

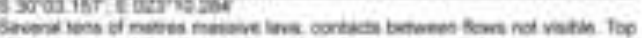

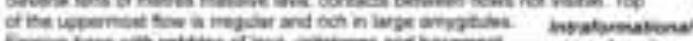

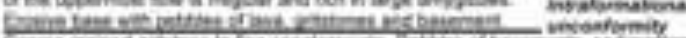

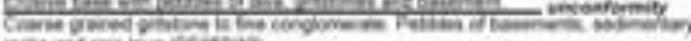

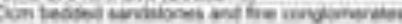

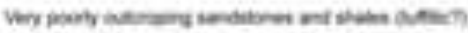

Ne nacres

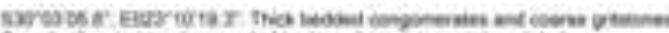

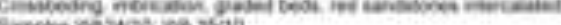

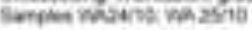

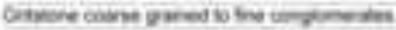

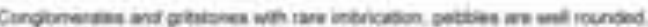

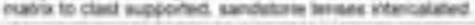

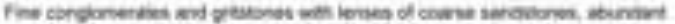

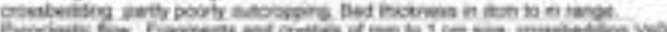

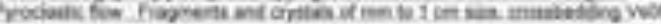

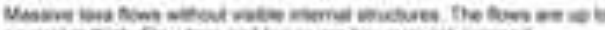

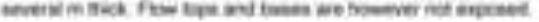



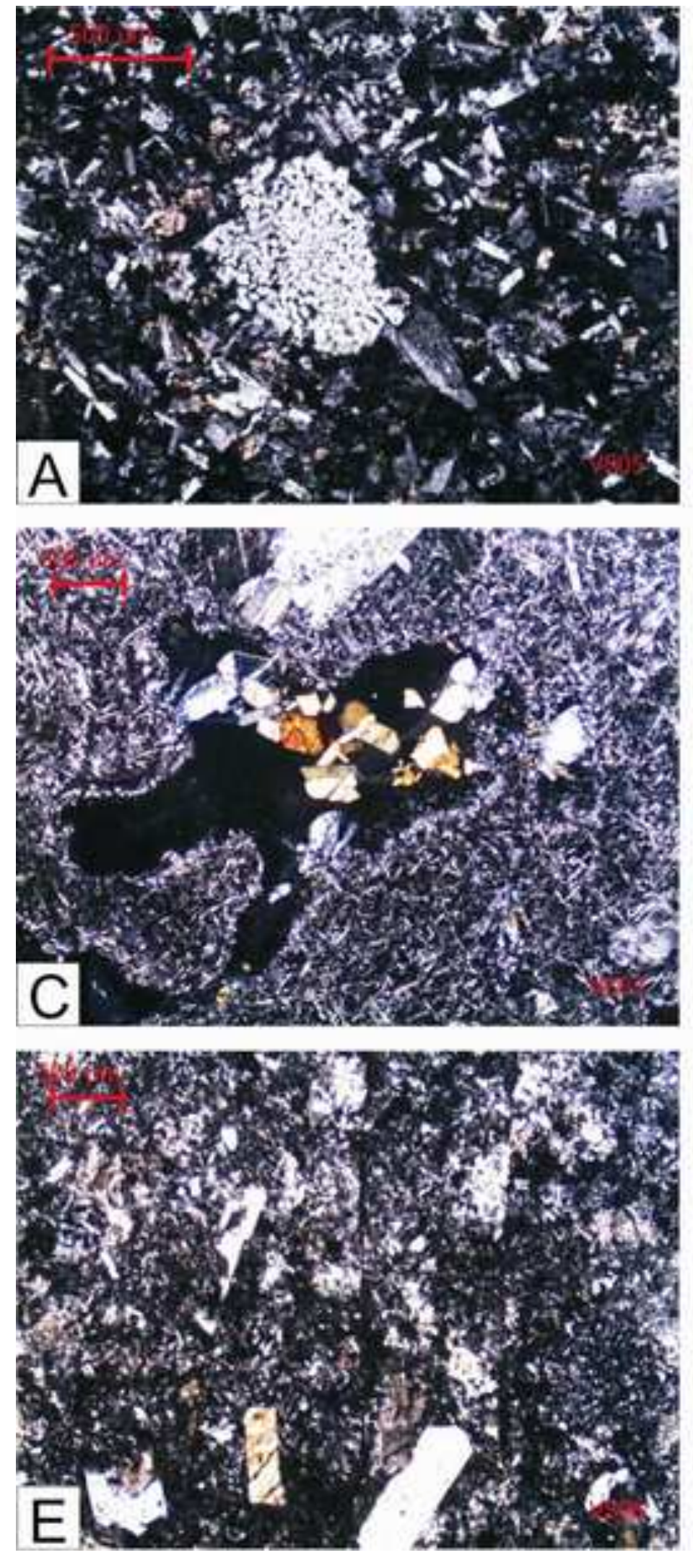
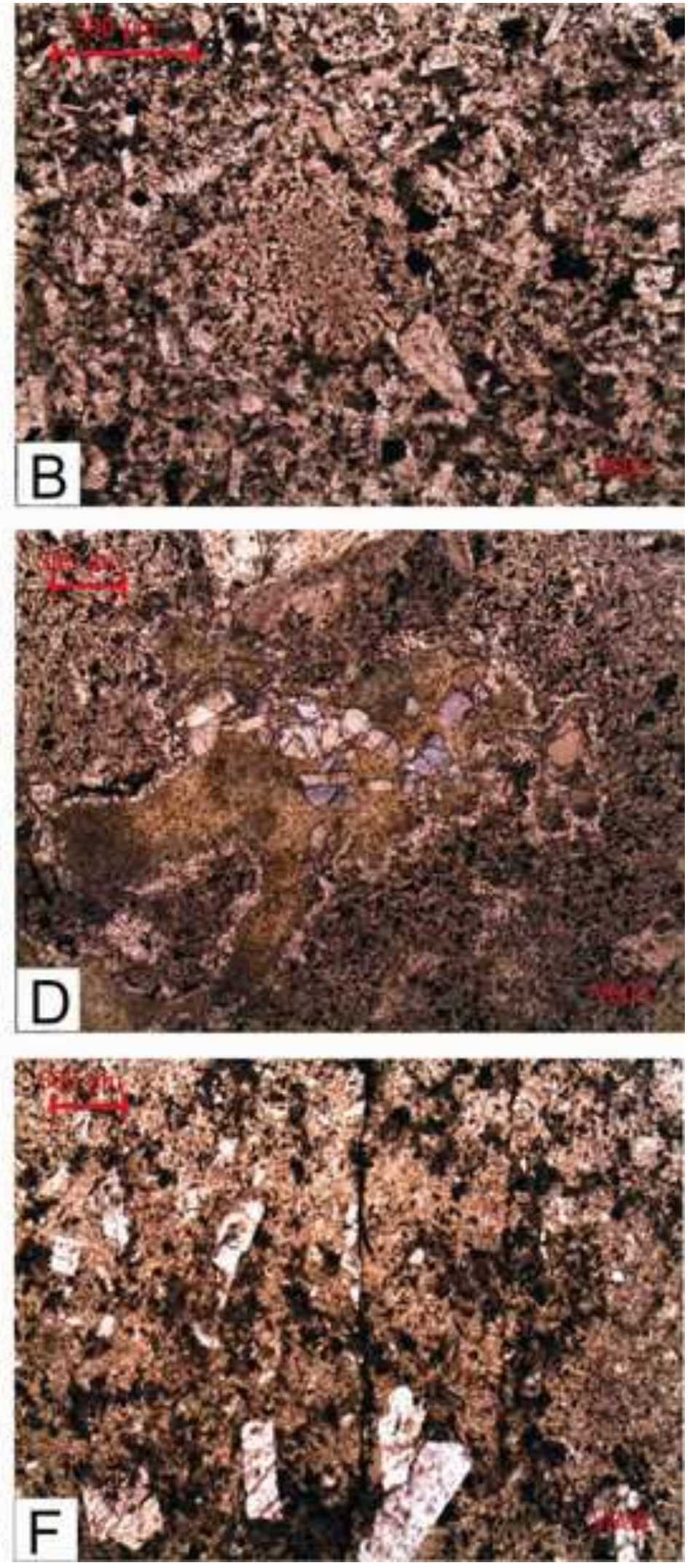

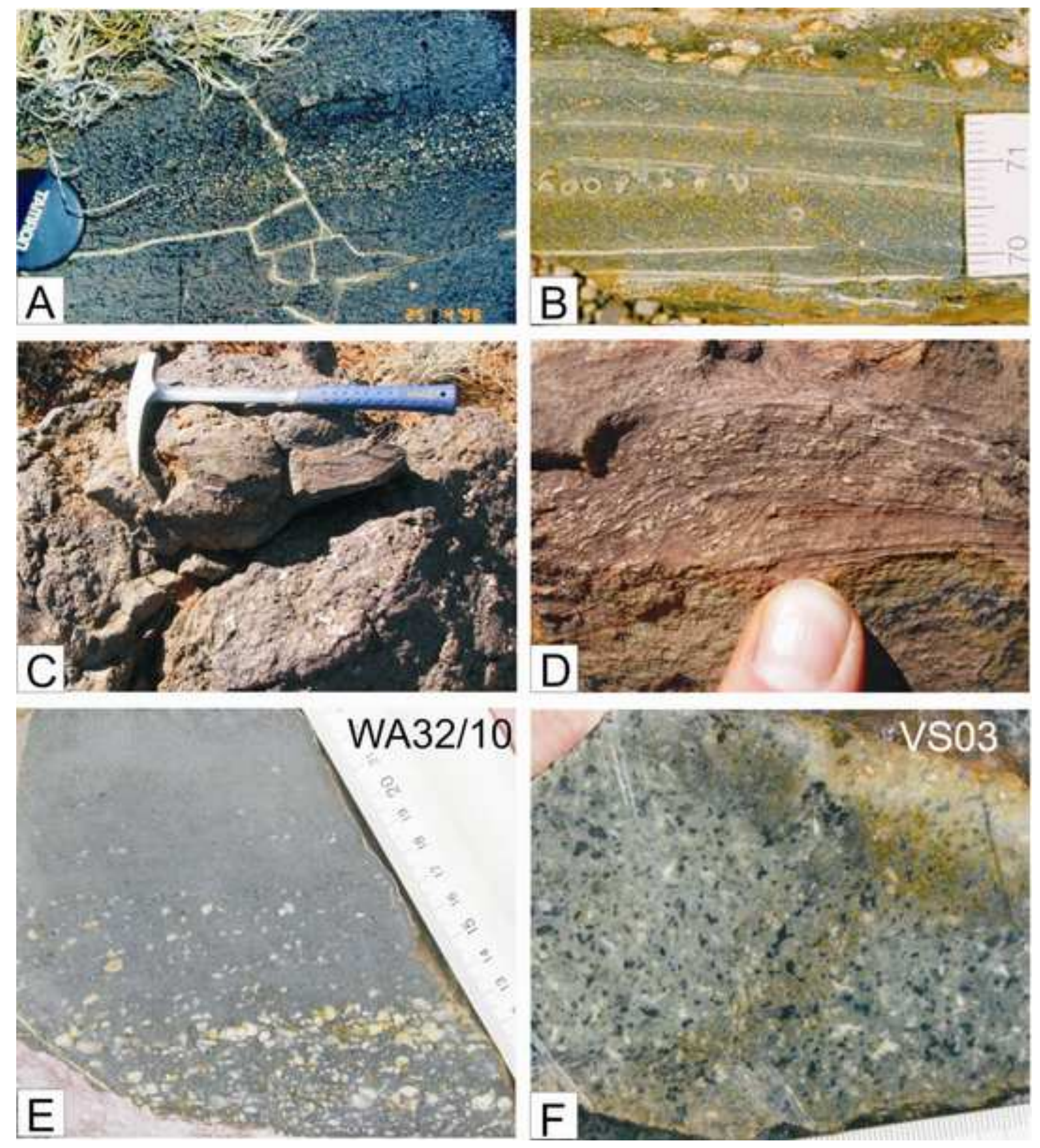



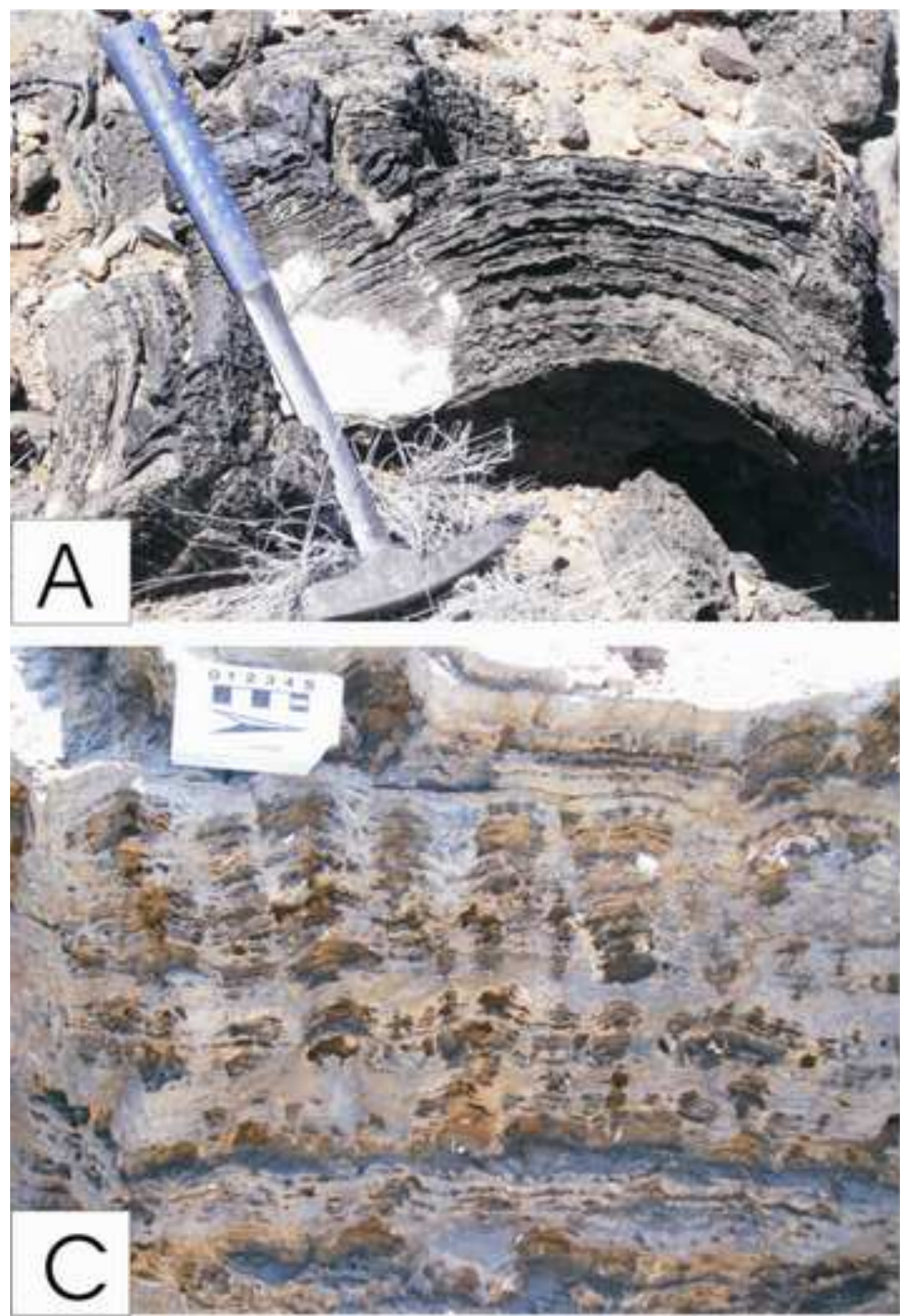

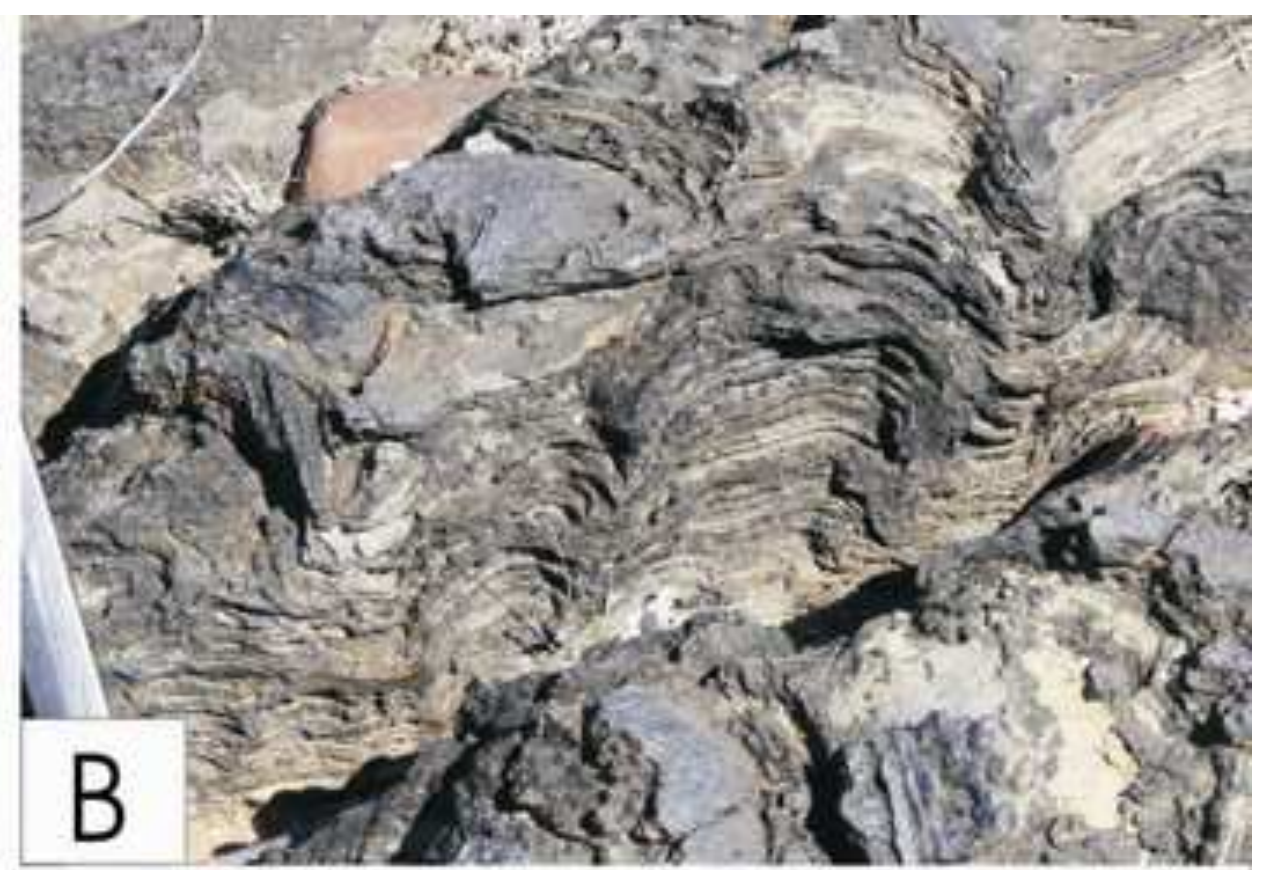

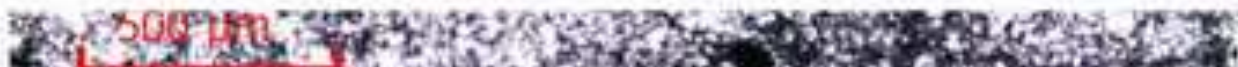

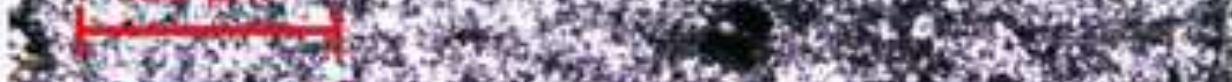

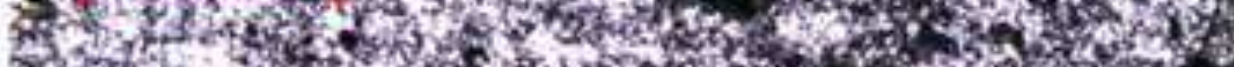

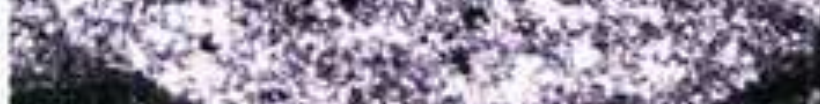

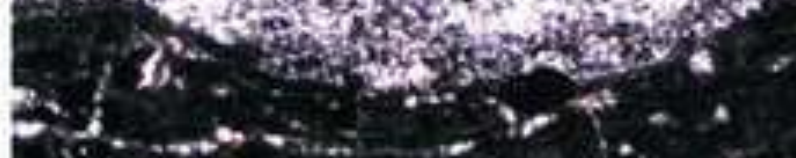

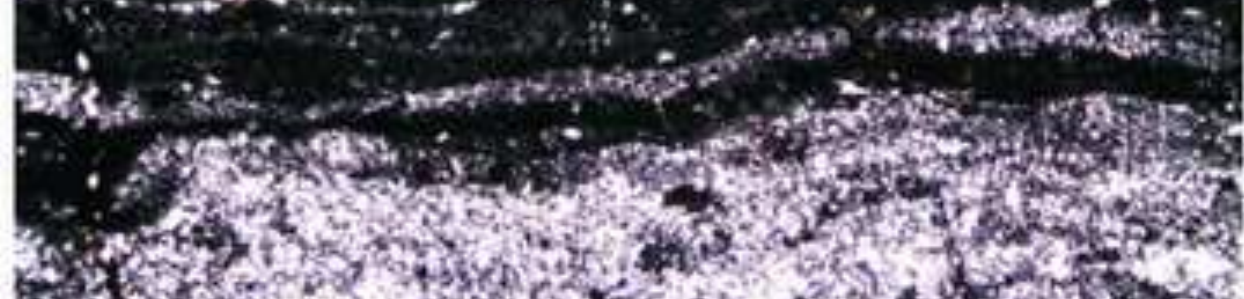

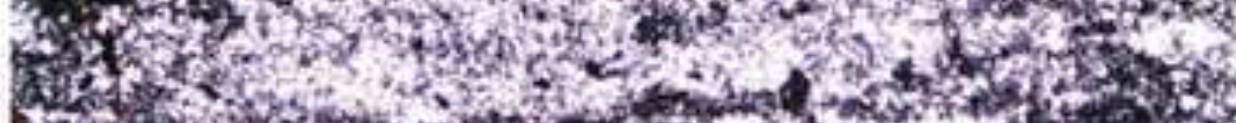

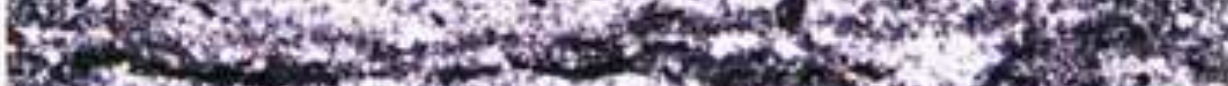

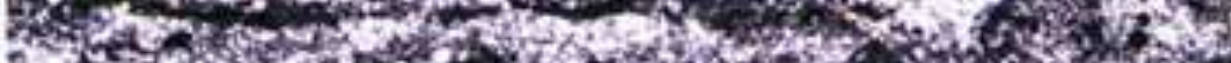

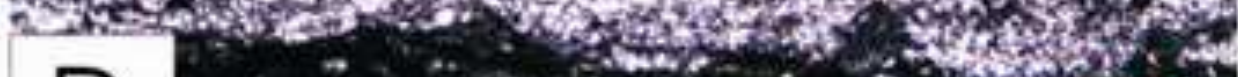

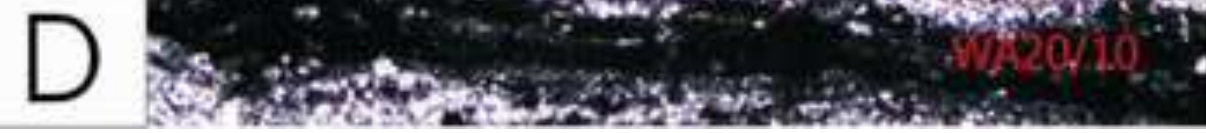




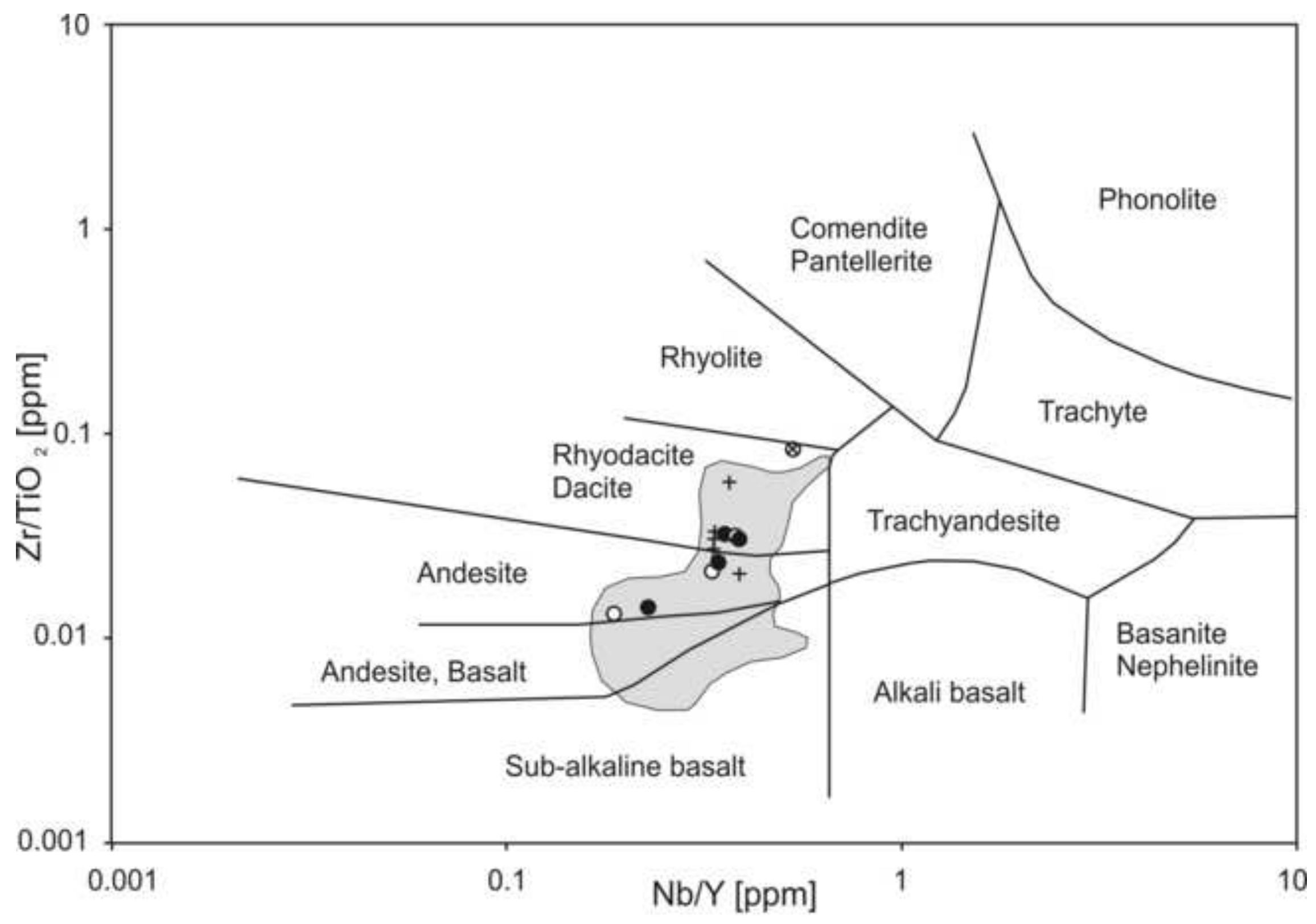

T'Kuip Fm.

+ Rietgat Fm. (data from Crow and Condie, 1988) $\left.\begin{array}{ll} & \text { Omdraaivlei Fm. } \\ \otimes & \text { Ongers River Fm. }\end{array}\right]$ (this study) Field of all Ventersdorp Supergroup volcanics (modified from Crow and Condie, 1988) 


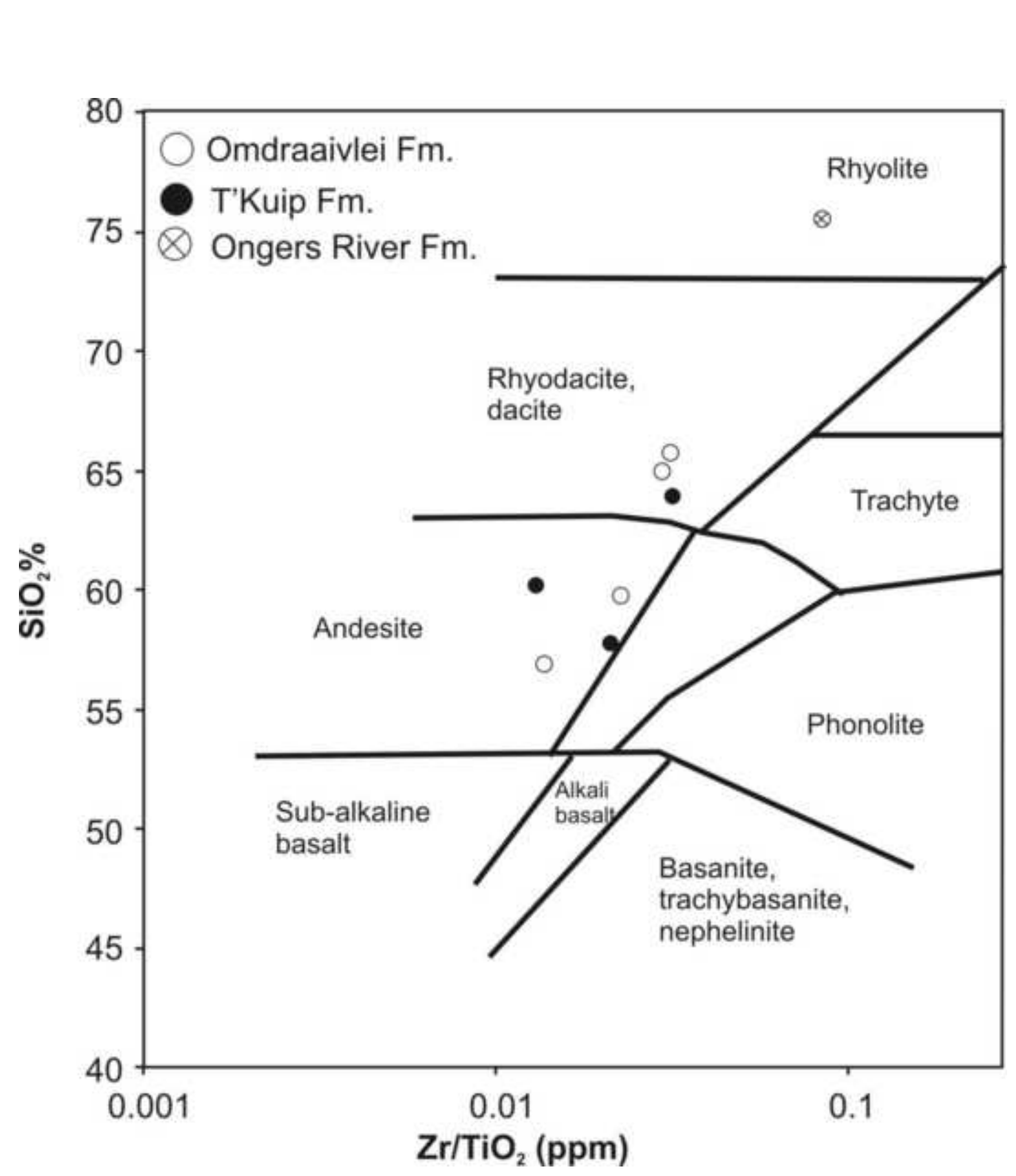

Figure 12 


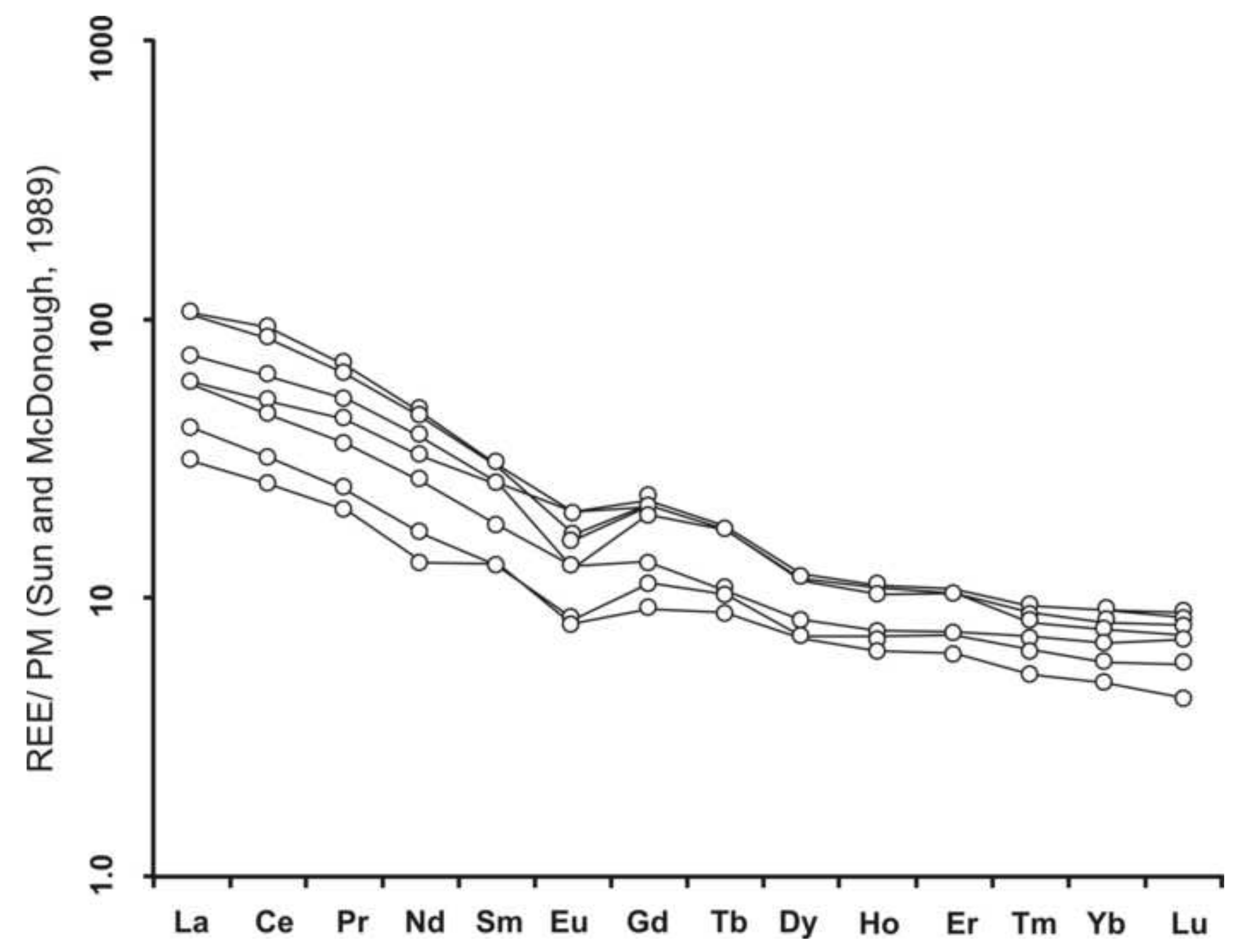




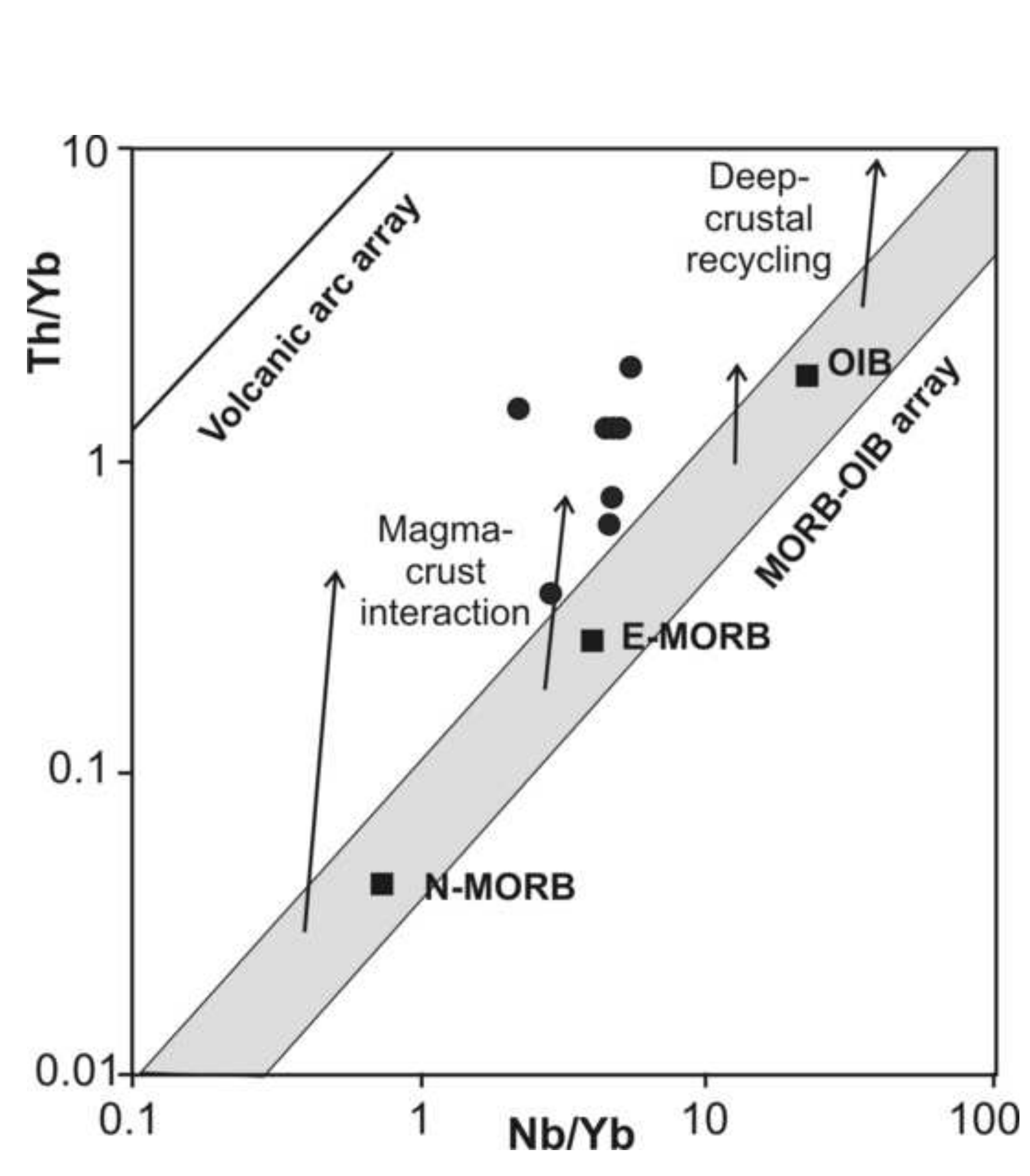

Figure 14
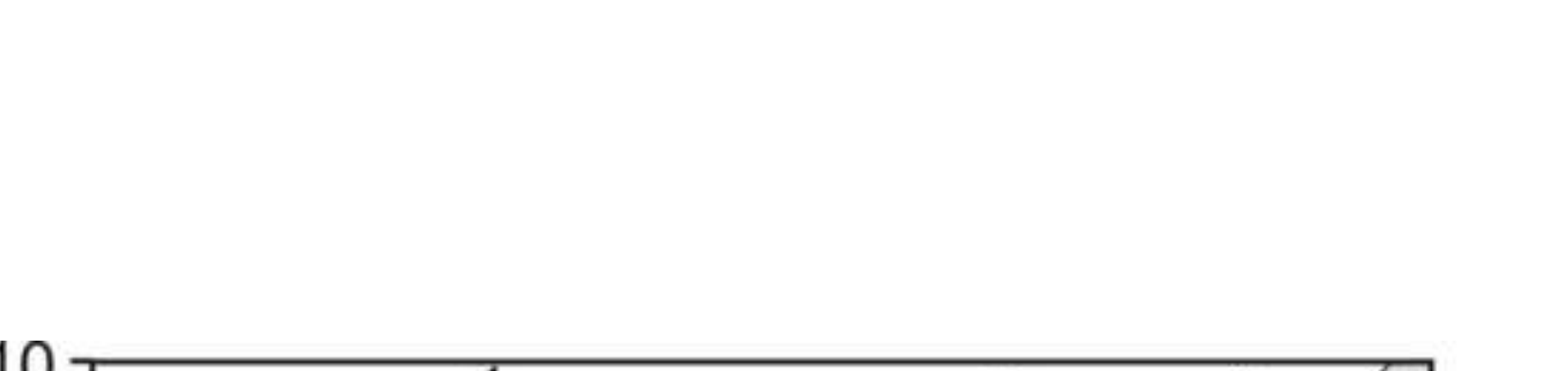

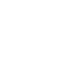


Figure 15
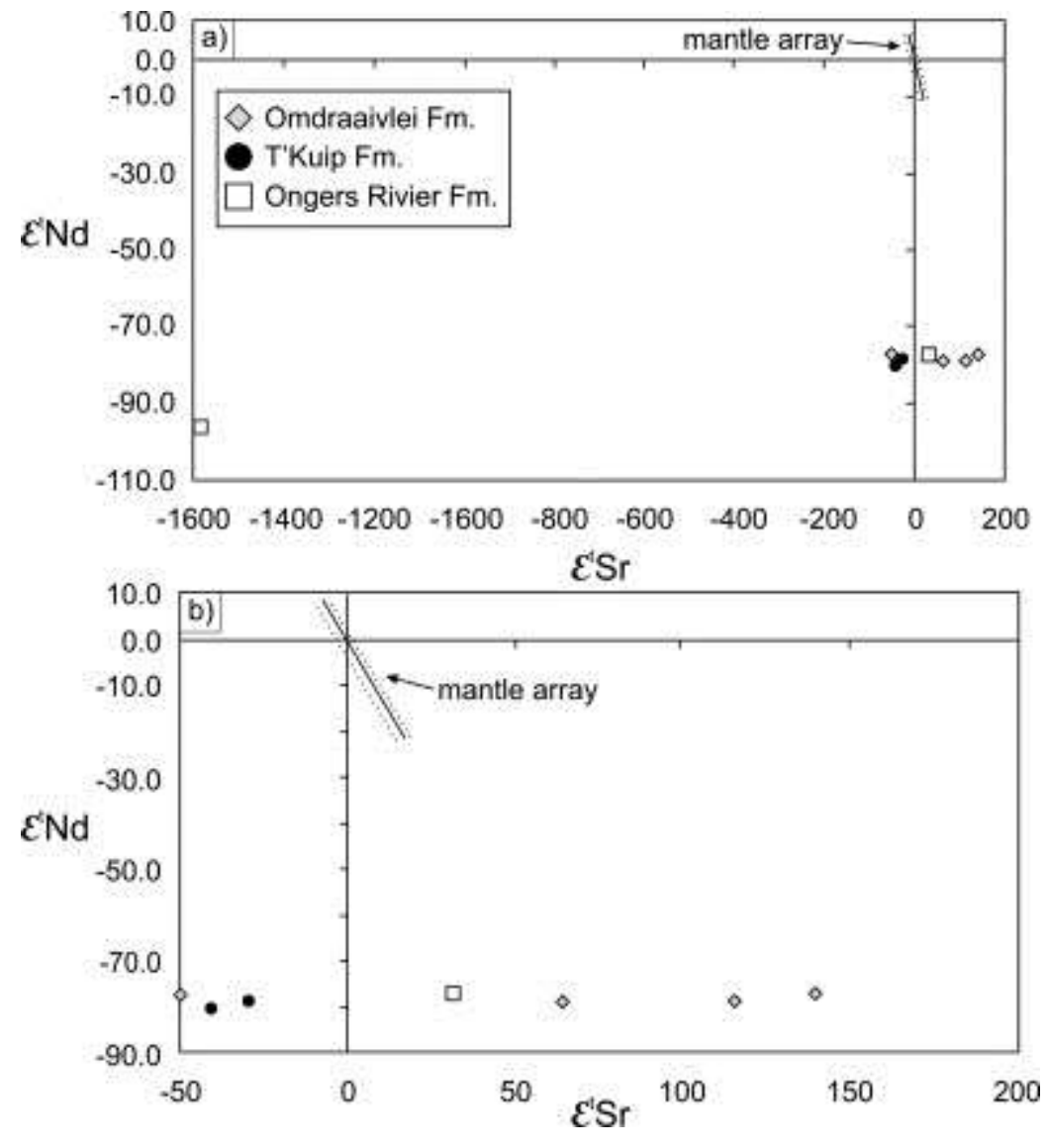


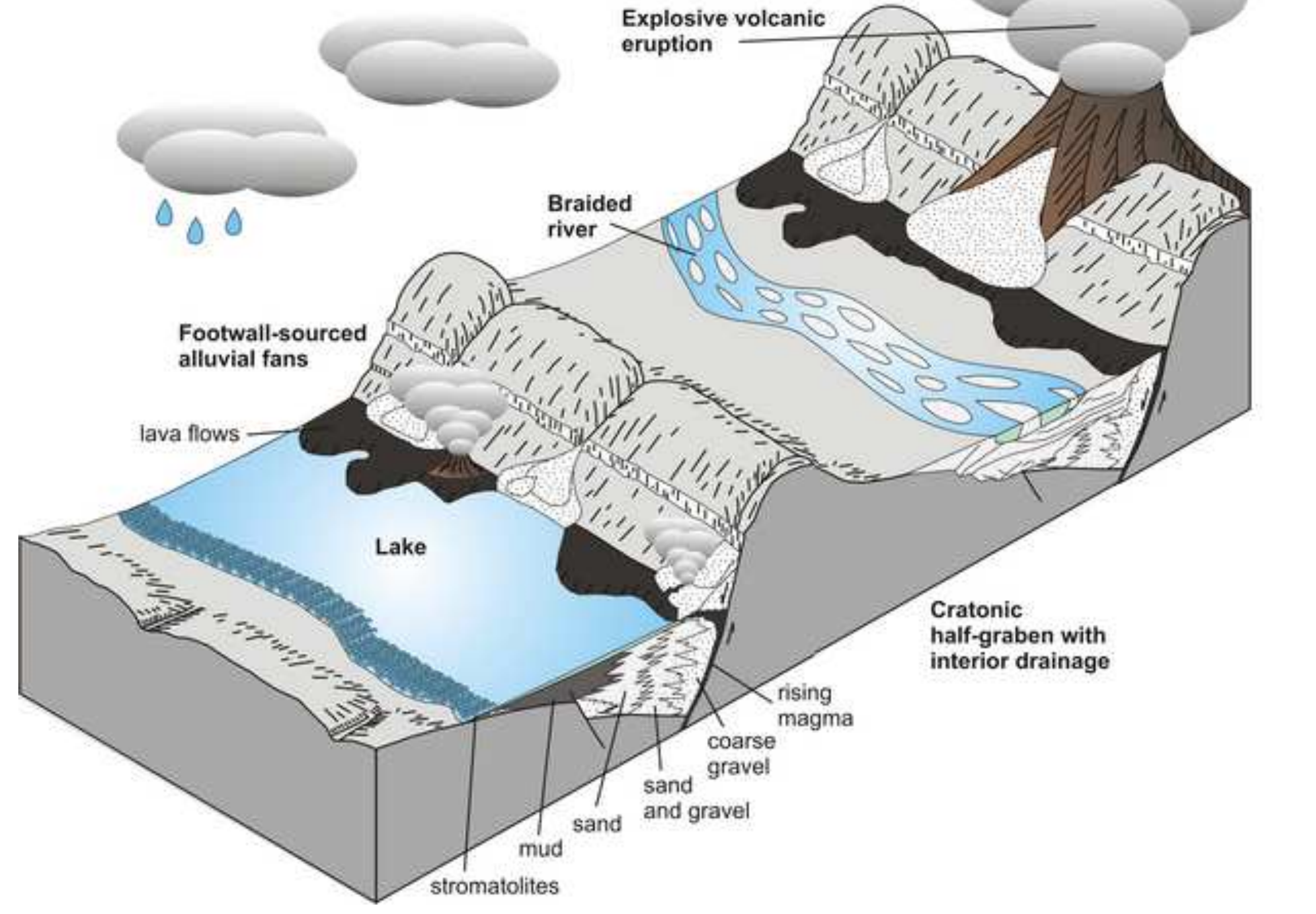

